\title{
Production of sourdough and gluten-free bread with brown rice and carioca and cowpea beans flours: biochemical, nutritional and structural characteristics
}

\author{
Produção de massa ácida e pães sem glúten com farinhas de arroz integral e feijões carioca e caupi: \\ características bioquímicas, nutricionais e estruturais \\ Producción de masa ácida y panes sin gluten con harinas de arroz integral y frijoles de carioca y \\ caupí: características bioquímicas, nutricionales y estructurales
}

Received: 11/27/2021 | Reviewed: 12/03/2021 | Accept: 12/04/2021| Published: 12/12/2021

Juliana Dara Rabêlo Silva
ORCID: https://orcid.org/0000-0002-8806-0053
Federal University of Jequitinhonha and Mucuri Valleys, Brazil
E-mail: julianasilvadr@gmail.com
Guilherme Caldeira Rosa
ORCID: https://orcid.org/0000-0002-8912-2594
Federal University of Jequitinhonha and Mucuri Valleys, Brazil
E-mail: guilhermecaldeirarosa@gmail.com
Nathália de Andrade Neves
ORCID: https://orcid.org/0000-0001-6936-2171
Federal University of Jequitinhonha and Mucuri Valleys, Brazil
E-mail: nathalia.neves@ict.ufvjm.edu.br
Maria Gabriela Vernaza Leoro
ORCID: https://orcid.org/0000-0001-7560-5651
Universidad San Francisco de Quito, Ecuador
E-mail: mgvernaza@usfq.edu.ec
Marcio Schmiele
ORCID: https://orcid.org/0000-0001-8830-1710
Federal University of Jequitinhonha and Mucuri Valleys, Brazil
E-mail: marcio.sc@ict.ufvjm.edu.br

\begin{abstract}
The gluten-free alternative flours and the application of natural fermentation in the breads production are promising technologies to improving sensory, structural and nutritional properties. The aim of this study was to evaluate the applicability and quality of gluten-free breads made with sour dough from wholegrain rice flours (BR and BRY), carioca beans (BP and BPY) and cowpea (BV and BVY). The sour doughs were prepared without and with the addition of biological yeast (Saccharomyces cerevisiae) represented by the letter "Y". The breads made from these doughs were subjected to the analysis of: $\mathrm{pH}$, titratable total acidity, color, water activity, moisture, image analysis, specific volume, instrumental texture, proximate composition and energy value. The results indicated higher ash, protein and dietary fiber content in BP and BV flours. At the end of fermentation, the BR and BRY masses showed greater acidity. The doughs made with beans showed greater expansion volumes. Lower volume, firmness and hardness were verified for BBRY bread and the opposite was verified for BVB bread. The BBV, BBVY, BBP and BBPY breads had higher ash, protein and dietary fiber contents and lower digestible carbohydrate content. BPB and BVB breads showed higher protein digestibility and the opposite was observed for BBRY $(70.60 \%)$, BPBY $(81.09 \%)$ and BVBY $(80.89 \%)$. The use of bean flour in the preparation of breads resulted in products rich in dietary fiber and proteins, especially carioca beans.
\end{abstract}

Keywords: Breadmaking; Dietary fiber; Latic acid bacteria; Protein digestibility; Yeast.

\section{Resumo}

A utilização de farinhas alternativas sem glúten e a aplicação de fermentação natural na fabricação de pães são tecnologias promissoras na melhoria das propriedades sensoriais, estruturais e nutricionais. O objetivo deste estudo foi verificar a aplicabilidade e a qualidade de pães glúten elaborados com massa ácida de farinhas integrais de arroz (BR e BRY), feijão carioca (BP e BPY) e feijão caupi (BV e BVY). As massas ácidas foram elaboradas sem e com a adição de fermento biológico (Saccharomyces cerevisiae) representado pela letra "Y". Os pães elaborados a partir dessas massas foram submetidos às análises de $\mathrm{pH}$, acidez total titulável, cor, atividade de água, umidade, análise de imagem, volume específico, textura instrumental, composição centesimal e valor energético. Os resultados indicaram maior teor de cinzas, proteínas e fibras alimentares nas farinhas BP e BV. Ao final da fermentação, as massas BR e BRY apresentaram maior acidez. As massas elaboradas com os feijões apresentaram maiores volumes de expansão. Menor volume, firmeza e dureza foi verificado no pão BBRY e o inverso foi verificado para o pão BVB. Os pães BBV, BBVY, 
BBP e BBPY apresentaram maiores teores de cinzas, proteínas e fibras alimentares e menor teor de carboidratos digeríveis. Os pães BPB e BVB apresentaram maior digestibilidade proteica e o contrário foi observado para BBRY $(70,60$ \%), BPBY $(81,09 \%)$ e BVBY $(80,89 \%)$. A utilização de farinhas de feijão na elaboração de pães resultou em produtos ricos em fibras alimentares e proteínas, sobretudo o feijão carioca.

Palavras-chave: Bactérias láticas; Digestibilidade proteica; Fibras alimentares; Levedura; Panificação.

\section{Resumen}

El uso de harinas alternativas sin gluten y la aplicación de fermentación natural en la fabricación de panes son tecnologías prometedoras para mejorar las propiedades sensoriales, estructurales y nutricionales. El objetivo de este estudio fue verificar la aplicabilidad y calidad de los panes sin gluten elaborados con masa ácida de harinas integrales de arroz (BR y BRY), frijoles carioca (BP y BPY) y caupí (BV y BVY). Las masas ácidas se prepararon sin y con la adición de levadura biológica (Saccharomyces cerevisiae) representada por la letra "Y". Los panes elaborados a partir de estas masas fueron sometidos a análisis de $\mathrm{pH}$, acidez total titulable, color, actividad de agua, humedad, análisis de imagen, volumen específico, textura instrumental, composición próxima y valor energético. Los resultados indicaron un mayor contenido de cenizas, proteínas y fibra dietética en las harinas BP y BV. Al final de la fermentación, las masas BR y BRY mostraron mayor acidez. Las masas elaboradas con frijol mostraron mayores volúmenes de expansión. Se verificó menor volumen, firmeza y dureza para el pan BBRY y lo contrario se verificó para el pan BVB. Los panes BBV, BBVY, BBP y BBPY tuvieron mayor contenido de cenizas, proteínas y fibra dietética y menor contenido de carbohidratos digestibles. Los panes BPB y BVB mostraron mayor digestibilidad de proteínas y lo contrario se observó para BBRY (70,60\%), BPBY $(81,09 \%)$ y BVBY $(80,89 \%)$. El uso de harina de frijol en la preparación de panes resultó en productos ricos en fibra dietética y proteínas, especialmente para los frijoles carioca.

Palabras clave: Bacterias lácticas; Digestibilidad de proteínas; Fibras alimentarias; Levadura; Panadería.

\section{Introduction}

The gluten-free market has been expanding in recent years (Kale \& Deshmukh, 2020). New consumer demands for food products with higher nutritional value or health benefits have driven the bakery industry to produce new foods and improve the nutritional quality of products (Coda et al., 2014; El Khoury et al., 2018). Using a mix of gluten-free flours is vital to obtain bread without gluten with good texture and adequate sensory and dietary properties (Arendt et al., 2008). Improving the manufacturing technologies is also essential, highlighting the natural fermentation biotechnology (Gallagher et al., .

There is great interest in using alternative flours in baking, such as legume flours, to improve the nutritional quality of products, mainly due to the high content of minerals, proteins and dietary fiber (Olojede et al., 2020). However, the use of alternative flours in the preparation of bread is restricted as they influence the final quality of bakery products (Gallagher et al., 2004).

Carioca (Phaseolus vulgaris L.) and cowpea (Vigna unguiculate L. Walp.) beans are recognized and officially standardized in Brazil by the Ministry of Agriculture, Livestock and Supply (Brasil- Ministério da Agricultura, 2008). These beans are widely consumed and represent an essential food in the diet of the Brazilian population because they are rich in nutrients and a source of proteins (Phillips et al., 2003). In addition, they contain digestible carbohydrates and dietary fibers consisting mainly of pectin, cellulose and hemicellulose (Figueroa, 2016). Furthermore, carioca and cowpea beans are rich in vitamins (especially B complex) (Celmeli et al., 2018; Köse, Ekbiç et al., 2019) and represent an excellent source of minerals, including potassium, calcium, iron, zinc and phosphorus (L. S Kato, 2014) and bioactive compounds with recognized antioxidant capacity (Vasantharaja et al., 2019; Yang et al., 2018; Zaheer et al., 2020).

The sourdough is obtained from natural and spontaneous fermentation. It consists of a mixture of flour and water fermented for a given period by lactic acid bacteria and yeasts present in the medium itself (Moroni et al., 2009). The main metabolic activities in the sourdough are related to acidification and fermentation, with lactic acid bacteria being the main responsible for providing acidity and stability in the dough by reducing the $\mathrm{pH}$ and increasing the levels of the organic acid (De Vuyst et al., 2014).

According to Gobbetti et al. (2014), during sourdough fermentation, essential changes occur such as acidification and enzyme activation, synthesis of microbial metabolites that influence the final quality of bakery products, regarding the nutritional 
and functional quality. In addition, it is well established that sourdough can reduce the starch digestibility and glycemic index in bread. A decrease of antinutritional factors is also highlighted, reducing phytate content and promoting the bioavailability of complex dietary fiber, phytochemicals, vitamins, minerals, amino acids and proteins (Bender et al., 2018; Bender \& Schönlechner, 2020; Coda et al.,, 2017; De Vuyst et al.,, 2016; Gobbetti et al., 2019, 2014).

Natural fermentation biotechnology can be efficient to improve the quality of bread made with legumes flours as it has the potential to explore the nutritional, functional and sensory characteristics of legumes and other alternative flours (Coda et al., 2014). Thus, the preparation of bread in combination with legume flours and sourdough biotechnology is a viable and promising alternative in manufacturing gluten-free bread, mainly because they present a low cost and an attractive nutritional and sensory profile. Given the above, this study aimed to verify the applicability and quality of gluten-free bread made with sourdough of brown rice and carioca and cowpea beans flours.

\section{Methodology}

This study was conducted using a scientific methodology for quantitative analysis and carried out in stages as proposed by Pereira et al. (2018). The works were carried out between the years 2018 and 2020.

\subsection{Raw materials used in the experiment}

Carioca and cowpea beans, cassava, potato and corn starches, fresh eggs, hydrogenated vegetable fat, soybean oil, sucrose, sodium chloride and biological yeast were purchased from a local market (Diamantina - MG). Rice flour, rice bran, lecithin and xanthan gum were purchased at the Central Market of Belo Horizonte - MG. The hydrolyzed soy protein was donated by the company HT Nutri - Camaquã - RS.

\subsection{Obtaining the flours}

Brown rice flour was obtained reconstituting with refined rice flour $(90 \%)$ and rice bran (10\%). The bean grains were dried in a TE-394/1 oven with air circulation and renewal at $1 \mathrm{~m} \cdot \mathrm{s}^{-1}$ (Tecnal, Piracicaba, BRA) at $35 \pm 2{ }^{\circ} \mathrm{C}$ for $24 \mathrm{~h}$ to reduce moisture level and facilitate the milling process. Afterward, the grains were processed in an MA-680 macro knife mill with the vertical rotor (Marconi, Piracicaba, BRA), equipped with a stainless-steel sieve with a 20 mesh opening $(0.85 \mathrm{~mm})$. The fractions that were not fully ground were crushed in an L28 blender (MK Mondial, Conceição do Jacuípe, BRA) for full use of the grains. Finally, the flours were placed in a low-density polyethylene package, sealed and stored at room temperature.

The particle size analysis was performed according to method 66-20.01 of the AACCI,(2010) adopted with sieves opening at $24(710 \mu \mathrm{m}), 30(600 \mu \mathrm{m}), 48(300 \mu \mathrm{m}), 60(250 \mu \mathrm{m})$ and $80(180 \mu \mathrm{m}) \mathrm{mesh}$ and a sieve shaker (Bertel, Caieras, BRA). The sieves were pouted on the base plate of a vibrating platform from the lowest (24) to the highest (80) mesh. The base and sieves were previously weighed and $100 \mathrm{~g}$ of the sample was added to the top sieve and the platform was adjusted to vibration speed 7 for 30 minutes. At the end of the time, all sieves were weighed and the retained weight recorded. The analysis was performed in triplicate and the results were expressed in percentage.

The percentage of the retained fraction was multiplied by conventional and constant factors that decreased from six to zero with the decrease of the sieve holes. The uniformity index (UI) and the fineness modulus (FM) (Eq. 1) were determined according to Zanotto and Bellaver, (1996). The geometric mean diameter (GMD) (Eq. 2) was determined using the equation of Henderson and Perry, (1976). 
Where: $\mathrm{FM}=$ Fineness modulus.

\subsection{Sourdough production}

The sourdoughs were prepared with a 50:50 ratio of water and flour (Coda, Kianjam, et al., 2017), and for the sourdoughs with bean flour, a percentage of 85:15 was considered (determined by pre-tests) for brown rice and carioca or cowpea bean flours. The samples were named according to their composition, as shown in Table 1.

The doughs were prepared by mixing the dry ingredients and water and submitted to complete homogenization in a PHP500 turbo mixer (Philco, Manaus, BRA). Then, the samples were stored in polypropylene containers, covered and submitted to a controlled temperature of 26 \pm 2 C, in a LUCA-161/01 BOD incubator (Lucadema, São José do Rio Preto, BRA). The doughs were submitted to a daily feeding for 18 days, with the addition of values corresponding to $50 \%$ of the initial dough, maintaining the proportion of 50:50 water/flour. On the $11^{\text {th }}$ day, the feeding procedure was modified from $50 \%$ to $75 \%$ of the initial value, making it possible to carry out daily analyzes for 18 days.

Table 1 - Samples codes according to their composition.

\begin{tabular}{|c|c|c|}
\hline Samples codes & & Raw material \\
\hline \multicolumn{3}{|l|}{ Brown rice flour } \\
\hline 1) & $\mathrm{BR}$ & Brown rice flour \\
\hline 2) & BRY & Brown rice flour + Yeast* \\
\hline \multicolumn{3}{|c|}{ Carioca bean flour (Phaseolus vulgaris) } \\
\hline 3) & $\mathrm{PB}$ & Brown rice flour + Carioca bean flour \\
\hline 4) & PBY & Brown rice flour + Carioca bean flour + Yeast $*$ \\
\hline \multicolumn{3}{|c|}{ Cowpea bean flour (Vigna unguiculata $\mathrm{L}$. Walp) } \\
\hline 5) & $\mathrm{VB}$ & Brown rice flour + Cowpea bean flour \\
\hline 6) & VBY & Brown rice flour + Cowpea bean flour + Yeast* \\
\hline
\end{tabular}

*For the biological yeast, the addition was carried out only on the first day of sourdough production, in the proportion of $1 \%$ in flour basis. Source: Authors (2021).

\subsection{Gluten-free bread formulation}

The ingredients amount for each formulation is shown in Table 2. The processing was done according to the flowchart shown in Figure 1.

Table 2 - Proportion of raw materials (in brown rice flour basis) and sourdough level of brown rice flour, carioca beans flour and cowpea bean flour added to the formulation of gluten-free bread

\begin{tabular}{llllllll}
\hline $\begin{array}{l}\text { Raw material (\% in brown rice flour } \\
\text { basis) }\end{array}$ & SB & BBR & BBRY & BPB & BPBY & BVB & BVBY \\
\hline Rice flour & 90 & 76.5 & 76.5 & 63 & 63 & 63 & 63 \\
Rice bran & 10 & 8.5 & 8.5 & 7 & 7 & 7 & 7 \\
Bean flour & 0 & 0 & 0 & 15 & 15 & 15 & 15 \\
Sourdough & 0 & 15 & 15 & 15 & 15 & 15 \\
Total & 100 & 100 & 100 & 100 & 100 & 100 & 100 \\
\hline
\end{tabular}

SB - Standard bread; BBR - Bread with sourdough of brown rice flour without yeast; BBRY - Bread with sourdough of brown rice flour with yeast; BPB - Bread with sourdough of carioca bean flour without yeast; BPBY - Bread with sourdough of carioca bean flour with yeast; BVB - Bread with sourdough of cowpea bean flour without yeast; BVBY - Bread with sourdough of cowpea bean flour with yeast.

Source: Authors (2021) 
In Brazil is no regulation regarding the use of biological yeast in fermented doughs, therefore considering the microflora present in sourdoughs, an international recommendation was adopted by Decree No. 93-1074, of September 13, 1993 (France, 1993), which determines a maximum limit up to $0.2 \%$ biological yeast (Saccharomyces cerevisiae) in the preparation of bread with sourdough. Therefore, for standard bread, a level of $1.4 \%$ of biological yeast should be used.

The remaining ingredients used in bread formulation (in flour basis) were: cassava starch (15\%), potato starch (15\%), corn starch $(15 \%)$, whole eggs (15\%), hydrogenated vegetable fat (4\%), soybean oil (4\%), sucrose (4\%), lecithin $(1 \%)$, commercial emulsifier (2\%) (composed of distilled fatty acid monoglycerides (INS 471), potassium stearate (INS 470), sorbitan monostearate (INS 491) and polyoxyethylene sorbitan monostearate (INS 435)), xanthan gum (1 \%), hydrolyzed soy protein (2 $\%$ ), sodium chloride ( $2 \%$ ) and drinkable water (added in a satisfactory amount for proper viscosity development of the mass, determined visually).

Figure 1 - Processing flowchart of gluten-free bread made with sourdough of brown rice, carioca and cowpea beans flours.

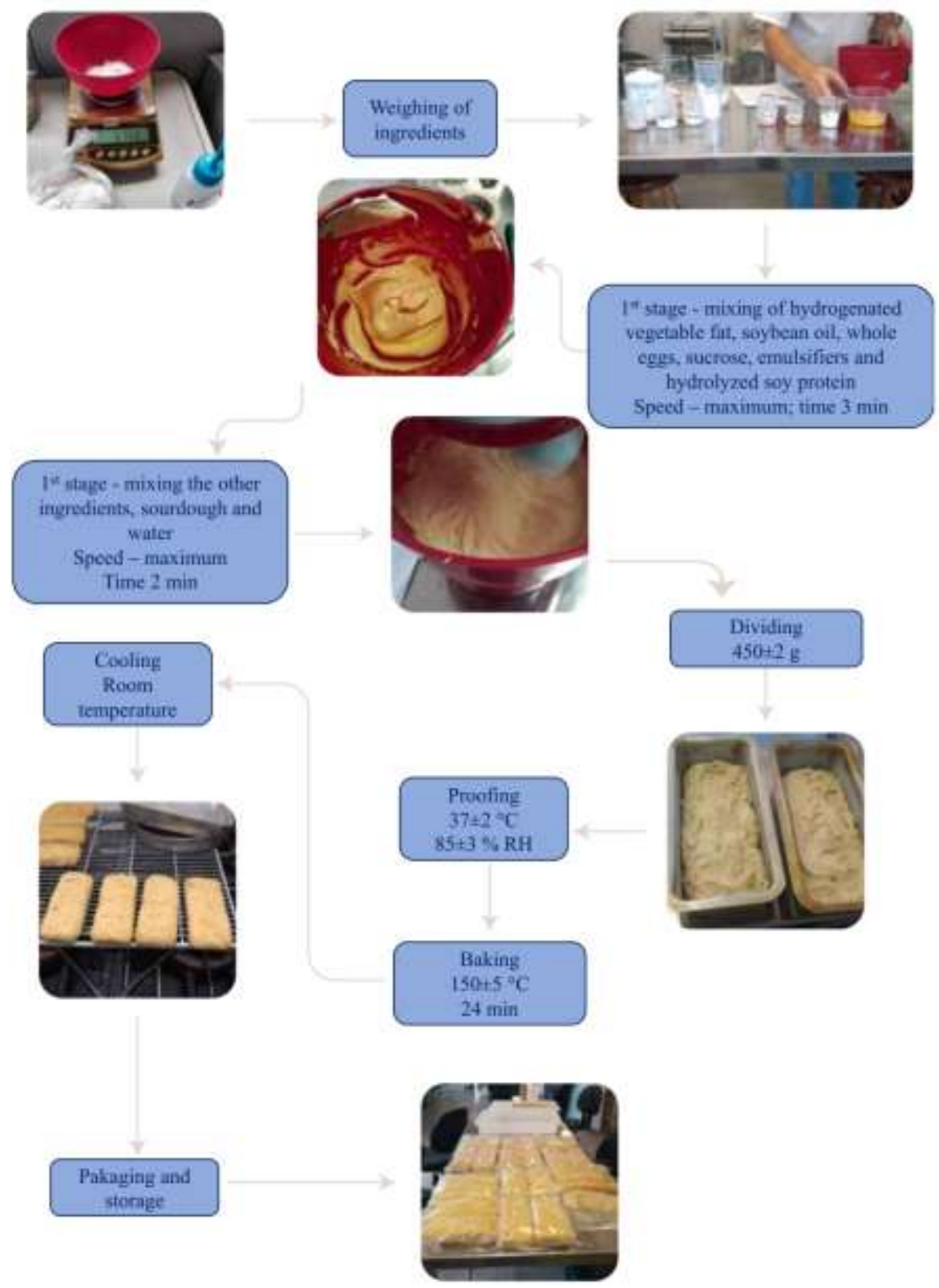

Source: Authors (2021). 
The ingredients were weighed in a BL-3200AS-BI semi-analytical electronic balance (Exacta, Ribeirão Preto, BRA) or an AUY220 analytical balance (Shimadzu, Kyoto, JPN). The processing method was carried out in two phases. The first phase consisted of forming a cream from the mixture of hydrogenated vegetable fat, soybean oil, whole eggs, sucrose, lecithin, commercial emulsifier and hydrolyzed soy protein. The combination of lipids was defined by pre-test and, together with the emulsifier, had the main objective to improve the technological action, favoring dough aeration through air entrapment into the gluten-free batter. The second phase was the homogenization of the dough by mixing the other ingredients, sourdough and water. The mixing was performed in a PHP500 turbo mixer (Philco, Manaus, BRA).

After obtaining homogeneous dough, $450 \pm 2 \mathrm{~g}$ of dough was placed in greased aluminum pans with $24 \mathrm{~cm}$ length, 10 $\mathrm{cm}$ width and $5 \mathrm{~cm}$ depth and submitted to proofing in a BOD at $37 \pm 2{ }^{\circ} \mathrm{C}$ and $85 \pm 3 \%$ relative humidity. The maximum growth size visually determined the proofing time for each sample in the pan. Then the proofed doughs were baked at $150 \pm 5{ }^{\circ} \mathrm{C}$ for 24 minutes in a ConvectionLine oven (Venâncio, Venâncio Aires, BRA). The loaves were unmolded and cooled at room temperature for 2 hours and stored in a low-density polyethylene package at room temperature $\left(\sim 18{ }^{\circ} \mathrm{C}\right)$ until analysis.

\subsection{Proximate composition of flours and bread}

The proximate composition of flours and bread was determined regarding the moisture (method 44-15.02), ash (method 08-01.01), proteins (method 46-13.01) and lipids (method 30-25.01) (AACCI, 2010). The factor used to convert nitrogen into protein was 6.25 for carioca and cowpea beans flours and 5.95 for brown rice flour. In bread, the conversion factor of 5.95 was maintained for all samples, considering rice flour as the principal constituent in the formulations. The digestible carbohydrates composed of available sugars and starch were analyzed by method 982.14 , and total dietary fiber was quantified by method 978.10 (AOAC, 2019). The total calorie value was calculated as described by Reis and Schmiele (2021) considering the converting method of Atwater (Merril \& Watt, 1973). All analyzes were performed in triplicate.

\subsection{Instrumental color of flours and bread crumb}

The loaves were mechanically sliced (Metalúrgica Venâcio Ltda., FPV12, Venâncio Aires, Brazil) and slices with $12 \mathrm{~mm}$ thickness were obtained. The instrumental color was determined in flours and crumbs of sliced bread through the method 14-22.01. (AACCI, 2010), using a Minolta CM-5 spectrophotometer (Konica, Tokyo, JPN). The test conditions were illuminant D65, visual angle of $10^{\circ}$ and calibration with reflectance specular excluded. Considering the CIE $L^{*} a^{*} b^{*}$ and $\mathrm{CIE} L^{*} C^{*} h^{*}$ color space, the instrumental color was evaluated. Furthermore, the value of $\Delta \mathrm{E}^{*}$ (total difference in color) in the bread was determined as described by (Neves, Gomes, Carmo, et al., 2020). This analysis was performed in triplicate.

\section{$2.7 \mathrm{pH}$ and total titratable acidity of sourdough and bread}

The $\mathrm{pH}$ analysis was performed according to the method 02-52.01 (AACCI, 2010), using a mPA210 pH meter (Tecnopon, Piracicaba, BRA). The total titratable acidity analysis was determined according to method 02-31.01 (AACCI, 2010) and the results were expressed in \% of lactic acid. In sourdough, these analyzes were performed daily before feeding the doughs. In breadmaking, the parameters were analyzed in the initial dough (before and after the proofing process) and the loaves. All analyzes were performed in triplicate.

\subsection{Specific analyzes of dough}

\subsubsection{Dough volume increase}

The sourdoughs were analyzed regarding dough volume increase based on the method described by Teotônio et al., (2021) according to the model presented in Equation 3. Before daily feeding, approximately $50 \mathrm{~g}$ of dough were placed in a 250 
$\mathrm{mL}$ beaker and the increase in dough volume was recorded every 10 minutes for 90 minutes. The results obtained were used to plot the graph referring to fermentation time $x$ increase of volume and the curve was integrated to calculate the area under the curve (AUC). The analysis was carried out in triplicate.

$$
\text { Dough volume increase }=\left[\mathrm{V}_{(\mathrm{t})}-\mathrm{V}_{(0)}\right] / \mathrm{V}_{(0)}
$$

Where: $\mathrm{V}_{(\mathrm{t})}=$ Volume measured in the time lapse between the beginning of fermentation and the volume recording; $\mathrm{V}_{(0)}=$ initial volume.

\subsubsection{Proofing time of dough in breadmaking}

The proofing time (in minutes) was evaluated as the time required for the dough to complete the maximum volume in the pan. Therefore, the analysis was carried out without repetition.

\subsection{Specific analyzes of bread}

The specific analyzes on the bread were carried out on the day after the manufacture, after approximately 18 hours. The measurements performed were water activity, specific volume, instrumental texture, image analysis, soluble nitrogen index and in vitro protein digestibility.

\subsubsection{Water activity}

The water activity was determined by the direct method using the 4TE Duo Aqualab hygrometer device (Decagon, São José dos Campos, BRA) as described by Neves et al. (2020). Analyzes were performed in triplicate.

\subsubsection{Specific volume}

The specific volume of the loaves was determined by the method 10-05.01 (AACCI, 2010) in triplicate. The results were expressed in $\mathrm{mL} \cdot \mathrm{g}^{-1}$.

\subsubsection{Instrumental texture of the crumb}

The crumb of the bread was measured concerning the texture profile analysis, as established by method 74-09.01 (AACCI, 2010). A TA-XT plus texturometer (Stable Micro Systems, Godalming, GBR) adopted with a P36R cylindrical probe and HDP/90 platform was used. Two slices of $12 \mathrm{~mm}$ in thickness each were subjected to double compression at a pre-test and test speed of $1.0 \mathrm{~mm} \cdot \mathrm{s}^{-1}$ and a post-test of $5 \mathrm{~mm} \cdot \mathrm{s}^{-1}$, with an interval of $2 \mathrm{~s}$, a distance of compression at $40 \%$ and the limiar force was $0.049 \mathrm{~N}$. The measurements were performed with eight repetitions and the parameters evaluated were: firmness $(\mathrm{N})$, hardness $(\mathrm{N})$, cohesiveness, gumminess $(\mathrm{N})$, chewiness $(\mathrm{N})$ and resilience.

\subsubsection{Image analysis of the alveoli of the slices}

According to Tasiguano et al., (2019), the slices of bread were evaluated for their alveolar structure. The values of total area, number of alveoli, average size of alveoli and circularity were assessed with four repetitions. Images were obtained by scanning at 600 dpi resolution in an MFC-895DW scanner (Brother, Ho Chi Minh, VTN) using black background paper. Images were saved in Joint Photographic Experts Group (jpeg) format and analyzed using Image J software (National Institutes of Health, Bethesda, USA). The measurements from the images were obtained in pixels and converted to $\mathrm{mm}$ using length values based on the shape's width $(10 \mathrm{~cm})$. Data were obtained after tracing the outline of the rectangular section of the bread slices. For cell analysis, images were set to 8-bit grayscale format, the contrast was adjusted, and Otsu's algorithm was chosen for thresholding. 


\subsubsection{Soluble nitrogen index}

The soluble nitrogen index was determined in bread based on method 46.24-01 (AACCI, 2010), with slight modifications. Initially, $15 \mathrm{~g}$ of sample and $200 \mathrm{~mL}$ of distilled water were crushed in a PMX700 mixer (Philco, Curitiba, BRA) at maximum speed for 8 minutes. Then, the suspension was transferred to a glass beaker for decantation. Subsequently, $15 \mathrm{~mL}$ of the supernatant were pipetted into Falcon tubes and centrifuged for 10 minutes in a 206BL centrifuge (Fanen, Guarulhos, BRA) at $2500 \times \mathrm{g}$. In the end, $10 \mathrm{~mL}$ of the supernatant phase were pipetted and transferred to micro Kjeldahl tubes, and the nitrogen value was determined by method 46.16-01 (AACCI, 2010). The soluble nitrogen index was calculated according to Equation 4.

Soluble nitrogen index $(\%)=($ water dispersible nitrogen/total nitrogen $) * 100$

Eq. 04

\subsubsection{In vitro protein digestibility}

Protein digestibility was determined according to Akeson \& Stahmann, (1964), with modifications. First, one gram of sample was placed in a $50 \mathrm{~mL}$ Falcon centrifuge tube with the addition of $15 \mathrm{~mL}$ of $0.1 \mathrm{M} \mathrm{HCl}$ and $1.5 \mathrm{mg}$ pepsin. The samples were incubated at $37 \pm 1{ }^{\circ} \mathrm{C}$ for $3 \mathrm{~h}$ in a shaking bath at $70 \mathrm{rpm}$. After incubation, the samples were neutralized with a $2 \mathrm{M} \mathrm{NaOH}$ solution until reaching a pH of 7.0 \pm 0.1 . Next, a pancreatin $(4 \mathrm{mg})$ solution with $0.2 \mathrm{M}$ phosphate buffer and $\mathrm{pH} 8.0(7.5 \mathrm{~mL})$ was prepared and added to the neutralized solution together with $1 \mathrm{~mL}$ of toluene. The sample was subjected to incubation for $24 \mathrm{~h} 37^{\circ} \mathrm{C}$. After incubation, the enzyme was inactivated with $10 \mathrm{~mL}$ of trichloroacetic acid $(20 \% \mathrm{~m} / \mathrm{v})$ under stirring. Finally, the solution was centrifuged at $2500 \mathrm{xg}$ for $20 \mathrm{~min}$ and the nitrogen of the supernatant was determined using the micro Kjeldahl methodology by method 46.16-01 (AACCI, 2010). For in vitro protein digestibility calculations (Eq. 5), a blank sample was considered.

In vitro protein digestibility $(\%)=\underline{(\% \text { protein from supernatant }-\% \text { protein from blank }) * 100}$

Eq. 05

$\%$ protein of the sample

\subsection{Statistical analysis}

The data were evaluated using analysis of variance (ANOVA) and Scott-Knott test $(P \leq 0.05)$, using Sisvar software (version 5.6). The results from $\mathrm{pH}$, total titratable acidity and dough volume increase of sourdough were submitted to linear regression. Pearson's correlation coefficient $(P \leq 0.05)$ was generated for the sourdough and bread data.

\section{Results and Discussion}

\subsection{Flours characterization}

\subsubsection{Particle size}

The results for particle size are shown in Table 3. It was observed that brown rice flour was thinner when compared to carioca and cowpea beans flours. The most significant proportion of brown rice flour was retained in sieves with smaller openings of 60 and 80 mesh $(250 \mu \mathrm{m}$ and $180 \mu \mathrm{m})$ and the largest particle size was observed in carioca bean flour, with the highest amount retained between the $24(710 \mu \mathrm{m})$ and $48(300 \mu \mathrm{m})$ mesh sieves. The uniformity index showed that there was a higher proportion of bean flour retention in sieves with larger openings (24-30 mesh) for carioca bean flour (17.42 $\pm 1.42 \%)$ and cowpea bean flour $(13.94 \pm 1.58 \%)$. On the other hand, there was higher retention in sieves with smaller holes ( $80-<180$ mesh) for brown rice flour, corresponding to $37.23 \pm 2.35 \%$. It was possible to verify the uniformity of the particles by the fineness modulus (FM) and classify the flours according to Henderson and Perry (1976) in coarse FM =4.10; medium FM = 3.20, fine 
$\mathrm{MF}=2.30$ and very fine $=1.50$. Thus, it can be observed that brown rice flour is fine $(\mathrm{FM}=2.88 \pm 0.03)$ with a smaller mean geometric diameter $(\mathrm{GMD})(768.24 \pm 16.69 \mu \mathrm{m})$ and carioca $(\mathrm{FM}=3.91 \pm 0.05 ; \mathrm{GMD}=1611.61 \pm 2.55 \mu \mathrm{m})$ and cowpea $(\mathrm{MF}=3.61 \pm 0.07 ; \mathrm{GMD}=1325.07 \pm 21.55 \mu \mathrm{m})$ bean flours are of medium particle size.

The size and uniformity of particles can change the water absorption capacity, dough viscosity, starch gelatinization and protein denaturation. Thus, it promotes changes in the structure of baked products, affecting the specific volume and crost and crumb texture of the bread. In addition, uniform particles tend to absorb water simultaneously, while particles with different sizes reduce the absorption speed and uniformity. Such characteristics can influence the technological properties of the products (Lapčíková et al., 2019).

Boukid et al. (2018) evaluated the particle size of legume flours and verified that the smaller the flour granulometry, the greater the bioavailability of gelatinized starch. However, the opposite was observed for flours with coarse granulometry since the water absorption was not uniform. Thus, some Maltese crosses of starch granules remained due to a lower degree of gelatinization. The insoluble dietary fiber content also affects the hydration rate of the particles, as they have greater water absorption capacity, reducing the availability of the solvent for the other hydrophilic components present in the flours.

Table 3 - Particle size distribution, uniformity index (UI), fineness module (FM) and geometric mean diameter (GMD) of brown rice and carioca and cowpea beans flours

\begin{tabular}{llll}
\hline Mesh $(\mu \mathbf{m})$ & Flours & Carioca bean & Cowpea bean \\
\cline { 2 - 4 } & Brown rice & $6.89 \pm 0.45^{\mathrm{a}}$ & $2.92 \pm 0.26^{\mathrm{b}}$ \\
\hline $24(710)$ & $0.83 \pm 0.03^{\mathrm{c}}$ & $10.53 \pm 0.93^{\mathrm{a}}$ & $11.02 \pm 1.33^{\mathrm{a}}$ \\
$30(600)$ & $1.07 \pm 0.22^{\mathrm{b}}$ & $60.88 \pm 0.66^{\mathrm{a}}$ & $47.60 \pm 0.10^{\mathrm{b}}$ \\
$48(300)$ & $25.24 \pm 1.41^{\mathrm{c}}$ & $13.91 \pm 0.89^{\mathrm{c}}$ & $29.30 \pm 0.54^{\mathrm{b}}$ \\
$60(250)$ & $36.58 \pm 0.71^{\mathrm{a}}$ & $4.70 \pm 0.78^{\mathrm{b}}$ & $2.19 \pm 0.13^{\mathrm{b}}$ \\
$80(180)$ & $30.08 \pm 1.36^{\mathrm{a}}$ & $2.79 \pm 0.12^{\mathrm{b}}$ & $6.22 \pm 1.36^{\mathrm{a}}$ \\
$>80(<180)$ & $7.14 \pm 0.98^{\mathrm{a}}$ & $17.42 \pm 1.42^{\mathrm{a}}$ & $13.94 \pm 1.58^{\mathrm{b}}$ \\
\hline UI $(24-30)$ & $1.90 \pm 0.19^{\mathrm{c}}$ & $74.79 \pm 0.28^{\mathrm{a}}$ & $76.89 \pm 0.63^{\mathrm{a}}$ \\
UI $(48-60)$ & $61.81 \pm 2.12^{\mathrm{b}}$ & $7.48 \pm 0.65^{\mathrm{b}}$ & $8.40 \pm 1.43^{\mathrm{b}}$ \\
UI $(80-<180)$ & $37.23 \pm 2.35^{\mathrm{a}}$ & $3.91 \pm 0.05^{\mathrm{a}}$ & $3.61 \pm 0.07^{\mathrm{b}}$ \\
\hline FM & $2.88 \pm 0.03^{\mathrm{c}}$ & $1611.61 \pm 2.55^{\mathrm{a}}$ & $1325.07 \pm 21.55^{\mathrm{b}}$ \\
GMD $(\mu \mathrm{m})$ & $768.24 \pm 16.69^{\mathrm{c}}$ & & \\
\hline
\end{tabular}

Means \pm standard deviation of three replicates. Means followed by the different letters on the row indicate significant differences by the ScottKnott test $(P \leq 0.05)$. Source: Authors (2021).

\subsubsection{Proximate composition}

The results of the proximate composition of the flours are shown in Table 4 . The moisture content was significantly lower in whole rice flours $(11.23 \pm 0.04 \%)$ when compared to carioca $(12.32 \pm 0.07 \%)$ and cowpea $(12.39 \pm<0.01 \%)$ bean flours. The moisture content in flour is an important quality parameter, as it is directly related to conservation and storage. High moisture content can favor and contribute to the development of microorganisms (spoilage and/or mycotoxin producers), in addition to chemical and biochemical alterations. Therefore, relatively less moisture is desirable to ensure quality and extend the shelf life of the product. The moisture content of the flours in this study meets the standards established by the National Health Surveillance Agency, in accordance with the Collegiate Board Resolution No. 263, of September 22, 2005, which sets the maximum limit of $15(\mathrm{~g} / 100 \mathrm{~g})$ of water content in flour (Brasil, 2005). 
Table 4 - Proximate composition $(\%)$ and total caloric value (kcal.100 $\mathrm{g}^{-1}$ ) of brown rice, carioca and cowpea flours

\begin{tabular}{llll}
\hline Component & Flours & & \\
\cline { 2 - 4 } & Brown rice & Carioca bean & Cowpea bean \\
\hline Moisture (wb) & $11.23 \pm 0.04^{\mathrm{b}}$ & $12.32 \pm 0.07^{\mathrm{a}}$ & $12.39 \pm<0.01^{\mathrm{a}}$ \\
Ashes (db) & $1.65 \pm 0.02^{\mathrm{c}}$ & $3.94 \pm<0.01^{\mathrm{a}}$ & $3.34 \pm 0.03^{\mathrm{b}}$ \\
Proteins (db) & $9.79 \pm 0.36^{\mathrm{c}}$ & $20.33 \pm 0.89^{\mathrm{b}}$ & $24.27 \pm 0.73^{\mathrm{a}}$ \\
Lipids (db) & $2.77 \pm 0.05^{\mathrm{b}}$ & $3.76 \pm 0.56^{\mathrm{a}}$ & $2.88 \pm 0.07^{\mathrm{b}}$ \\
Digestible carbohydrates (db), expressed in glucose & $70.47 \pm 2.62^{\mathrm{a}}$ & $36.42 \pm 2.46^{\mathrm{b}}$ & $35.64 \pm 1.52^{\mathrm{b}}$ \\
Total dietary fibers (db) & $15.32 \pm 2.55^{\mathrm{b}}$ & $35.91 \pm 2.97^{\mathrm{a}}$ & $33.91 \pm 1.32^{\mathrm{a}}$ \\
Total caloric values & $345.95 \pm 10.32^{\mathrm{a}}$ & $259.39 \pm 13.06^{\mathrm{b}}$ & $265.40 \pm 5.32^{\mathrm{b}}$ \\
\hline
\end{tabular}

Means \pm standard deviation of three replicates. Means followed by the different letters on the row indicate significant differences by the ScottKnott test $(P \leq 0.05)$. wb - wet basis; db - dry basis. Source: Authors (2021).

Cowpea flour had the highest ash content $(3.34 \pm 0.03 \%)$ followed by carioca bean flour $(3.94 \pm 0.01 \%)$ and the opposite was found in brown rice flour $(1.65 \pm 0.02 \%)$. Ashes refer to the mineral content and the highest concentration is located on the grains outside layers (pericarp, testa and aleurone) (Kalschne et al., 2020). A more significant amount of inorganic matter is available in wholemeal flours because they are made with their integuments (Zapata-Luna et al., 2021). Considering that the flours used were wholemeal, it is inferred that the carioca and cowpea beans flours naturally have higher mineral content in their composition. Similar results were found by (Kato, 2014), in which carioca bean had higher ash content (4.10 $\pm 0.16 \%)$ and cowpea had lower ash content $(3.37 \pm 0.27 \%)$. Rocchetti et al. (2019) have investigated and determined the approximate composition of several kinds of cereal and legumes (black beans: ash $3.32 \%$, proteins $23.70 \%$; and black rice: ash $1.44 \%$, proteins $10.62 \%)$.

Minerals play an essential role in the body's functioning, as they help transport oxygen, energy metabolism, water balance, tissue and bones structure and act as cofactors for enzymatic activity (Cozzolino, 2016). In a study by (Kato et al., 2015), different chemical elements ( $\mathrm{Br}, \mathrm{Ca}, \mathrm{Co}, \mathrm{Cs}, \mathrm{Fe}, \mathrm{K}, \mathrm{Mo}, \mathrm{Na}, \mathrm{Rb}, \mathrm{Sc}$ and $\mathrm{Zn}$ ) were identified in cowpea and carioca beans, in diverse concentrations, being: higher concentration of $\mathrm{Na}, \mathrm{Br}, \mathrm{Cs}, \mathrm{Mo}$, and $\mathrm{Zn}$ in cowpea and higher concentration of $\mathrm{Ca}$, $\mathrm{Co}$, $\mathrm{K}$ and Sc in carioca beans. The composition of different bean cultivars can be influenced by extrinsic factors related to the production environment, such as the composition and concentration of minerals present in the soil, fertilizers used, and plant growth and development (Carvalho et al., 2014).

Cowpea and carioca bean flours have the highest protein content $(24.27 \pm 0.70 \%$ and $20.33 \pm 0.89 \%$, respectively), while the lowest protein content was found in brown rice flour $(9.79 \pm 0.36 \%)$. Beans are an important source of protein for human nutrition and complement cereal proteins. Legumes and pulses are especially rich in lysine and tryptophan (essential amino acids). At the same time, cereals are poor in this one but rich in sulfur amino acids (methionine and cysteine) to complete mutually (Cozzolino, 2016). Therefore, beans have a low acquisition cost when compared to animal protein. Furthermore, legume proteins have limitations due to their low digestibility because of the presence of antinutritional compounds such as trypsin, chymotrypsin and amylases responsible for inhibiting the activity of proteases. It affects the digestion of food in the gastrointestinal tract, reducing protein hydrolysis and digestibility, resulting in a lower bioavailability of essential amino acids (Avilés-Gaxiola et al.,2018).

Several methods have been tested and adopted by the food industry (such as extrusion, drying, roasting, soaking, autoclaving, fermentation and germination) to reduce the activity of anti-nutritional compounds. Several factors can be involved in the efficiency of this reduction, such as the technique used, duration, temperature, moisture and size of samples subjected to treatment (Vagadia et al.,2017). However, the objective of such reduction is mainly focused on increasing and improving the nutritional quality of legumes due to their capacity for nutritional enrichment and technological applicability in the food industry, even though the proteins present in beans and certain legumes can have low allergenicity, good solubility capacity, attractive 
emulsifying, gelling and structuring function to be used in food production (Boyle et al., 2018).

Spontaneous fermentation (sourdough) can reduce antinutritional compounds in beans due to the production of proteolytic enzymes by microorganisms present in the dough. As a benefit, an increase in protein digestibility and bioavailability can be observed. For example, Worku and Sahu, (2017) demonstrated that natural fermentation in red bean grains reduced antinutritional factors (phytates, trypsin inhibitor activity, saponins, tannins and raffinose oligosaccharide). In addition, it increased up to $90 \%$ protein digestibility after fermentation.

The lipid content was higher in carioca bean flour $(3.76 \pm 0.56 \%)$. On the other hand, brown rice flour had higher digestible carbohydrate content and energy value ( $70.47 \pm 2.72 \%$ and $345.95 \pm 10.32 \mathrm{kcal} 100 \mathrm{~g}^{-1}$, respectively), and there was no significant difference between carioca and cowpea beans flours. The opposite was observed for the dietary fiber content of carioca $(35.91 \pm 2.37 \%)$ and cowpea $(33.91 \pm 1.32 \%)$ bean flours.

The replacement of gluten and non-gluten flours with legume flour has been applied by our Research Group to improve the nutritional quality of the bakery and cereals-based products such as bread (Santos et al.,2017; Schmiele et al., 2017), frozen doughs (Rodrigues et al., 2021; Teotônio, et al., 2021; Teotônio et al., 2021), gluten-free dough rheology ( Souza et al., 2017), extruded products (Hashimoto et al., 2020, 2021), pasta and noodles (Mastelini et al., 2018; M. Schmiele et al., 2019; Schmiele, Silva, Costa, Rodrigues, \& Chang, 2011), muffins (Lima et al.,, 2021; Lima et al., 2021; Souza et al., 2021), cereal bars (Santos et al., 2021) and biscuits and cookies (Bolanos et al.,2019; Crivelenti et al., 2013). A study carried out by Frota et al. (2009), using up to $30 \%$ of bean flour to replace wheat flour in biscuits and cake, found an increase in the content of proteins, phosphorus, iron, potassium, magnesium and zinc, demonstrating that the use of flour of beans was able to increase the nutritional value of these products. Furthermore, Olapade and Oluwole (2013) found an increase in the levels of proteins, lipids, dietary fibers and ash in bread enriched with up to $15 \%$ of bean flour. These results demonstrate that carioca and cowpea flours have an excellent nutritional profile, mainly due to the high amount of minerals, proteins and dietary fiber.

\subsubsection{Instrumental color}

The results of the instrumental color analysis can be seen in Table 5. Brown rice flour had the highest $L^{*}$ value (lightness) (85.69 \pm 0.08 ), while the opposite was observed for carioca bean flour with $L^{*}$ of $80.39 \pm 0.05$. When monitoring the parameter $a^{*}$ (in which the variation goes from green to red) and parameter $b^{*}$ (which varies from blue to yellow), it was noticed that the carioca bean flour had a more significant predominance in the red color hue ( $\left.a^{*}=2.62 \pm 0.03\right)$. In contrast, cowpea flour showed a more considerable predominance of yellowness $\left(b^{*}=13.56 \pm 0.16\right)$. These results demonstrate that the brown rice flour was lighter while the carioca bean flour was darker. This color variation is a function of the composition of the flours, particularly in beans, and the hue of their respective integuments may have influenced the color. 
Table 5 - Instrumental color of brown rice, carioca and cowpea bean flours.

\begin{tabular}{llll}
\hline Parameter & \multicolumn{1}{l}{ Flours } & \\
\cline { 2 - 4 } & Brown rice & Carioca bean & Cowpea bean \\
\hline$L^{*}$ & $85.69 \pm 0.08^{\mathrm{a}}$ & $80.39 \pm 0.05^{\mathrm{c}} \pm 0.10^{\mathrm{b}}$ \\
$a^{*}$ & $0.81 \pm 0.02^{\mathrm{c}}$ & $2.62 \pm 0.03^{\mathrm{a}}$ & $0.99 \pm 0.03^{\mathrm{b}}$ \\
$b^{*}$ & $12.79 \pm 0.06^{\mathrm{b}}$ & $12.25 \pm 0.02^{\mathrm{c}}$ & $13.56 \pm 0.16^{\mathrm{a}}$ \\
Estimated color & & & \\
& & & \\
Real appearance & & & \\
\hline
\end{tabular}

Means \pm standard deviation of three replicates. Means followed by the different letters on the row indicate significant differences by the ScottKnott test $(P \leq 0.05)$. Obtained by software Nix Color Convert. Source: Authors (2021).

\subsection{Sourdough characterization}

\subsection{1 $\mathrm{pH}$ and total titratable acidity}

The $\mathrm{pH}$ and total titratable acidity results are shown in Table 6 and Table 7, respectively. The treatments initially presented a higher $\mathrm{pH}$ value and a lower total titratable acidity value. At first, it was observed that the doughs added with yeast (Saccharomyces cerevisiae) - BRY, PBY and VBY presented higher acidity, represented by the lower pH value and higher total titratable acidity value. This result refers to the initial metabolism of yeasts, which releases carbon dioxide $\left(\mathrm{CO}_{2}\right)$. This release is mainly the result of the metabolism of fermentable carbohydrates (sucrose, glucose, fructose and maltose). $\mathrm{When}^{\mathrm{CO}_{2}} \mathrm{meets}$ water, it undergoes a chemical reaction forming carbonic acid $\left(\mathrm{H}_{2} \mathrm{CO}_{3}\right)$, this is a weak acid that dissociates into $\mathrm{H}^{+}$and $\mathrm{HCO}_{3}$. This dissociation increases the concentration of hydrogen ion $\left(\mathrm{H}^{+}\right)$in the medium, thus resulting in a lower $\mathrm{pH}(\mathrm{Aissa}$, Bahloul, Monteau, \& Le-Bail, 2015). Therefore, an initial increase in acidity is expected and quickly observed in doughs added with yeast.

Variations in $\mathrm{pH}$ values were observed for all samples followed by stability between the doughs with and without the addition of yeast, clearly evidenced on the $10^{\text {th }}$ day in BR $(3.93 \pm 0.01)$, BRY $(3.98 \pm 0.01)$, PB $(4.01 \pm 0.01), P B Y(4.01 \pm 0.01)$, VB $(4.02 \pm 0.01)$ and VBY (4.01 \pm 0.01$)$. A different behavior was observed in the acidification of the dough made with carioca bean flour (total titratable acidity: $\mathrm{PB}=2.13 \pm 0.02 \%$ and $\mathrm{PBY}=2.01 \pm 0.01 \%$, in lactic acid) and cowpea (total titratable acidity: $\mathrm{VB}=1.90 \pm 0.22 \%$ and $\mathrm{VBY}=2.04 \pm 0.03 \%$, in lactic acid), in which there was no direct relationship between the $\mathrm{pH}$ and total titratable acidity parameters, which was not expected since the $\mathrm{pH}$ and total titratable acidity are inversely related. Thus, a buffering effect is suggested, probably due to the higher content of proteins present in the form of polypeptides. During the development and maturation of the sourdough, hydrolysis of proteins occurs, resulting in the release of macromolecules with lower molar weight. Such behavior was verified by (Coda, et al., 2017) using fava flour (Vicia faba L.). 
Table 6 - pH of sourdough made with brown rice and carioca and cowpea beans flours

\begin{tabular}{|c|c|c|c|c|c|c|}
\hline \multirow{2}{*}{ Time (days) } & \multicolumn{6}{|l|}{ pH } \\
\hline & $\mathbf{B R}$ & BRY & PB & PBY & VB & VBY \\
\hline 0 & $6.69 \pm 0.04^{\mathrm{a}}$ & $6.12 \pm 0.02^{c}$ & $6.18 \pm 0.03^{b}$ & $6.09 \pm<0.01^{\mathrm{d}}$ & $6.13 \pm 0.01^{\mathrm{c}}$ & $6.07 \pm 0.01^{\mathrm{d}}$ \\
\hline 1 & $5.28 \pm 0.05^{\mathrm{d}}$ & $5.78 \pm 0.01^{\mathrm{a}}$ & $5.47 \pm 0.03^{c}$ & $5.66 \pm 0.03^{b}$ & $5.20 \pm 0.05^{\mathrm{e}}$ & $5.77 \pm 0.01^{\mathrm{a}}$ \\
\hline 2 & $4.35 \pm 0.02^{\mathrm{e}}$ & $4.59 \pm 0.02^{\mathrm{b}}$ & $4.37 \pm 0.05^{\mathrm{e}}$ & $4.48 \pm 0.02^{\mathrm{c}}$ & $4.43 \pm 0.05^{\mathrm{d}}$ & $4.75 \pm 0.03^{\mathrm{a}}$ \\
\hline 3 & $4.24 \pm 0.01^{\mathrm{c}}$ & $4.24 \pm 0.01^{\mathrm{c}}$ & $4.30 \pm<0.01^{b}$ & $4.27 \pm<0.01^{\mathrm{c}}$ & $4.38 \pm<0.01^{\mathrm{a}}$ & $4.31 \pm<0.01^{b}$ \\
\hline 4 & $4.10 \pm 0.02^{c}$ & $4.09 \pm<0.01^{\mathrm{c}}$ & $4.29 \pm 0.01^{\mathrm{a}}$ & $4.14 \pm<0.01^{b}$ & $4.29 \pm 0.01^{\mathrm{a}}$ & $4.16 \pm<0.01^{b}$ \\
\hline 5 & $4.17 \pm<0.01^{\mathrm{b}}$ & $4.06 \pm<0.01^{\mathrm{c}}$ & $4.29 \pm 0.05^{\mathrm{a}}$ & $4.18 \pm 0.03^{b}$ & $4.28 \pm<0.01^{\mathrm{a}}$ & $4.19 \pm 0.01^{b}$ \\
\hline 6 & $4.08 \pm 0.01^{\mathrm{c}}$ & $4.11 \pm 0.01^{\mathrm{c}}$ & $4.24 \pm 0.03^{\mathrm{a}}$ & $4.18 \pm 0.01^{\mathrm{b}}$ & $4.23 \pm<0.01^{\mathrm{a}}$ & $4.08 \pm<0.01^{\mathrm{c}}$ \\
\hline 7 & $4.00 \pm 0.04^{\mathrm{c}}$ & $4.00 \pm<0.01^{\mathrm{c}}$ & $4.02 \pm 0.02^{\mathrm{c}}$ & $4.05 \pm 0.01^{\mathrm{b}}$ & $4.15 \pm<0.01^{\mathrm{a}}$ & $4.06 \pm<0.01^{b}$ \\
\hline 8 & $3.98 \pm 0.02^{\mathrm{b}}$ & $3.92 \pm 0.01^{\mathrm{c}}$ & $4.03 \pm 0.01^{\mathrm{a}}$ & $4.00 \pm<0.01^{\mathrm{b}}$ & $4.06 \pm 0.04^{\mathrm{a}}$ & $4.07 \pm<0.01^{\mathrm{a}}$ \\
\hline 9 & $4.03 \pm 0.02^{\mathrm{b}}$ & $4.03 \pm 0.01^{\mathrm{b}}$ & $4.08 \pm<0.01^{\mathrm{a}}$ & $4.02 \pm 0.01^{\mathrm{b}}$ & $4.08 \pm<0.01^{\mathrm{a}}$ & $4.09 \pm<0.01^{\mathrm{a}}$ \\
\hline 10 & $3.93 \pm<0.01^{\mathrm{b}}$ & $3.98 \pm 0.01^{\mathrm{a}}$ & $4.01 \pm 0.01^{\mathrm{a}}$ & $4.01 \pm 0.01^{\mathrm{a}}$ & $4.02 \pm<0.01^{\mathrm{a}}$ & $4.01 \pm<0.01^{\mathrm{a}}$ \\
\hline 11 & $3.88 \pm<0.01^{\mathrm{c}}$ & $4.04 \pm 0.04^{\mathrm{a}}$ & $3.95 \pm 0.01^{b}$ & $3.95 \pm 0.01^{\mathrm{b}}$ & $3.95 \pm 0.02^{\mathrm{b}}$ & $3.96 \pm 0.02^{\mathrm{b}}$ \\
\hline 12 & $3.97 \pm 0.01^{\mathrm{b}}$ & $3.96 \pm<0.01^{\mathrm{b}}$ & $4.01 \pm 0.01^{\mathrm{a}}$ & $4.04 \pm 0.02^{\mathrm{a}}$ & $4.03 \pm<0.01^{\mathrm{a}}$ & $4.02 \pm<0.01^{\mathrm{a}}$ \\
\hline 13 & $3.92 \pm 0.01^{\mathrm{b}}$ & $3.93 \pm<0.01^{\mathrm{b}}$ & $3.88 \pm 0.02^{\mathrm{b}}$ & $3.90 \pm 0.01^{\mathrm{b}}$ & $3.97 \pm 0.01^{\mathrm{a}}$ & $3.95 \pm 0.01^{\mathrm{a}}$ \\
\hline 14 & $3.96 \pm 0.07^{b}$ & $3.88 \pm 0.01^{\mathrm{c}}$ & $4.02 \pm 0.02^{\mathrm{a}}$ & $4.03 \pm 0.02^{\mathrm{a}}$ & $4.06 \pm 0.01^{\mathrm{a}}$ & $4.05 \pm<0.01^{\mathrm{a}}$ \\
\hline 15 & $3.89 \pm 0.02^{\mathrm{c}}$ & $3.86 \pm<0.01^{\mathrm{c}}$ & $3.97 \pm 0.02^{b}$ & $4.01 \pm 0.01^{\mathrm{a}}$ & $4.02 \pm 0.01^{\mathrm{a}}$ & $4.04 \pm<0.01^{\mathrm{a}}$ \\
\hline 16 & $3.87 \pm 0.01^{\mathrm{c}}$ & $3.99 \pm 0.05^{\mathrm{b}}$ & $4.02 \pm 0.01^{\mathrm{b}}$ & $4.03 \pm 0.01^{\mathrm{a}}$ & $4.05 \pm 0.01^{\mathrm{a}}$ & $4.06 \pm<0.01^{\mathrm{a}}$ \\
\hline 17 & $3.84 \pm 0.01^{\mathrm{c}}$ & $3.76 \pm 0.01^{\mathrm{d}}$ & $3.97 \pm 0.01^{\mathrm{b}}$ & $4.02 \pm<0.01^{\mathrm{a}}$ & $4.02 \pm<0.01^{\mathrm{a}}$ & $4.03 \pm<0.01^{\mathrm{a}}$ \\
\hline 18 & $3.83 \pm 0.01^{\mathrm{c}}$ & $3.91 \pm 0.03^{\mathrm{b}}$ & $3.98 \pm 0.02^{\mathrm{a}}$ & $4.01 \pm 0.01^{\mathrm{a}}$ & $4.01 \pm 0.01^{\mathrm{a}}$ & $4.02 \pm<0.01^{\mathrm{a}}$ \\
\hline p-value & 0.014 & 0.046 & 0.012 & 0.011 & $<0.001$ & 0.040 \\
\hline $\mathrm{R}$ - multiple & 0.722 & 0.652 & 0.727 & 0.733 & 0.829 & 0.662 \\
\hline $\mathrm{R}^{2}$ & 0.522 & 0.425 & 0.529 & 0.537 & 0.686 & 0.438 \\
\hline $\mathrm{R}^{2}$ adjusted & 0.419 & 0.302 & 0.428 & 0.438 & 0.619 & 0.317 \\
\hline
\end{tabular}

Means \pm standard deviation of three replicates. Means followed by the different letters on the row indicate significant differences by the Scott-Knott test $(P \leq$ 0.05). BR - Sourdough of brown rice flour without yeast; BRY - Sourdough of brown rice flour with yeast; PB - Sourdough of carioca bean flour without yeast; PBY - Sourdough of carioca bean flour with yeast; VB - Sourdough of cowpea bean flour without yeast; VBY - Sourdough of cowpea bean flour with yeast. Source: Authors (2021).

Another factor that may have resulted in the heterogeneity between the production of $\mathrm{CO}_{2}$, lactic acid, and acetic acid by lactic bacteria may explain the lack of correlation between $\mathrm{pH}$ and total titratable acidity. A slight variation can be observed on the $12^{\text {th }}$ day due to the change in feeding the doughs, but the rapid reestablishment of the $\mathrm{pH}$ in the doughs is noticeable. From the $13^{\text {th }}$ day onwards, a similar behavior was observed between the treatments with and without the addition of yeast and, at the end of the $18^{\text {th }}$ day, the $\mathrm{pH}$ of the doughs was stable, and the doughs with brown rice flour were significantly more acidic regarding the $\mathrm{pH}$ : BR $(3.83 \pm 0.01)$ and $\mathrm{BRY}(3.91 \pm 0.03)$.

Aplevicz (2013) studied the fermentation kinetics of lactic acid bacteria (Lactobacillus paracasei) and yeasts (Saccharomyces cerevisiae) and demonstrated that lactic acid bacteria resulted in a dough with lower $\mathrm{pH}$ and higher total titratable acidity. However, a trend of approximation of the results over time was observed for the different microorganisms. 
Table 7 - Total titratable acidity of sourdough made with brown rice and carioca and cowpea beans flours

\begin{tabular}{|c|c|c|c|c|c|c|}
\hline \multirow{2}{*}{ Time (days) } & \multicolumn{6}{|c|}{ Total titratable acidity (\% in lactic acid) } \\
\hline & BR & BRY & $\mathbf{P B}$ & PBY & VB & VBY \\
\hline 0 & $0.12 \pm 0.01^{\mathrm{b}}$ & $0.14 \pm 0.01^{\mathrm{b}}$ & $0.20 \pm 0.01^{\mathrm{a}}$ & $0.23 \pm<0.01^{\mathrm{a}}$ & $0.21 \pm 0.01^{\mathrm{a}}$ & $0.24 \pm 0.01^{\mathrm{a}}$ \\
\hline 1 & $0.41 \pm 0.01^{\mathrm{b}}$ & $0.31 \pm 0.01^{\mathrm{b}}$ & $0.51 \pm 0.02^{\mathrm{a}}$ & $0.42 \pm 0.01^{\mathrm{b}}$ & $0.54 \pm<0.01^{\mathrm{a}}$ & $0.37 \pm 0.01^{\mathrm{b}}$ \\
\hline 2 & $0.81 \pm 0.02^{\mathrm{c}}$ & $0.67 \pm 0.02^{\mathrm{d}}$ & $1.14 \pm 0.02^{\mathrm{a}}$ & $0.94 \pm 0.02^{\mathrm{b}}$ & $1.08 \pm 0.01^{\mathrm{a}}$ & $0.81 \pm 0.02^{\mathrm{c}}$ \\
\hline 3 & $0.94 \pm 0.04^{\mathrm{b}}$ & $0.83 \pm 0.01^{\mathrm{c}}$ & $1.08 \pm 0.01^{\mathrm{a}}$ & $1.03 \pm 0.02^{\mathrm{a}}$ & $1.02 \pm 0.01^{\mathrm{a}}$ & $1.04 \pm 0.03^{\mathrm{a}}$ \\
\hline 4 & $1.23 \pm 0.05^{\mathrm{a}}$ & $1.28 \pm 0.02^{\mathrm{a}}$ & $0.90 \pm<0.01^{\mathrm{c}}$ & $0.96 \pm 0.01^{\mathrm{b}}$ & $0.99 \pm 0.01^{\mathrm{b}}$ & $1.04 \pm 0.02^{\mathrm{b}}$ \\
\hline 5 & $1.25 \pm 0.05^{\mathrm{b}}$ & $1.42 \pm 0.02^{\mathrm{a}}$ & $0.94 \pm 0.03^{\mathrm{d}}$ & $1.02 \pm 0.03^{\mathrm{d}}$ & $1.01 \pm<0.01^{\mathrm{d}}$ & $1.10 \pm 0.01^{\mathrm{c}}$ \\
\hline 6 & $1.26 \pm 0.03^{\mathrm{b}}$ & $1.34 \pm 0.03^{\mathrm{a}}$ & $0.93 \pm 0.02^{\mathrm{d}}$ & $0.97 \pm 0.02^{\mathrm{d}}$ & $1.04 \pm 0.03^{\mathrm{c}}$ & $1.39 \pm 0.03^{\mathrm{a}}$ \\
\hline 7 & $1.35 \pm 0.02^{\mathrm{c}}$ & $1.63 \pm 0.01^{\mathrm{a}}$ & $1.63 \pm 0.10^{\mathrm{a}}$ & $1.48 \pm 0.05^{\mathrm{b}}$ & $1.20 \pm 0.01^{\mathrm{d}}$ & $1.68 \pm 0.02^{\mathrm{a}}$ \\
\hline 8 & $1.54 \pm 0.04^{\mathrm{c}}$ & $1.92 \pm 0.18^{\mathrm{a}}$ & $1.76 \pm 0.08^{\mathrm{b}}$ & $1.90 \pm 0.04^{\mathrm{a}}$ & $1.48 \pm 0.02^{\mathrm{c}}$ & $1.76 \pm 0.06^{\mathrm{b}}$ \\
\hline 9 & $1.45 \pm 0.02^{\mathrm{c}}$ & $1.44 \pm 0.04^{\mathrm{c}}$ & $1.56 \pm<0.01^{\mathrm{b}}$ & $1.78 \pm 0.07^{\mathrm{a}}$ & $1.59 \pm 0.04^{\mathrm{b}}$ & $1.70 \pm 0.03^{\mathrm{a}}$ \\
\hline 10 & $1.62 \pm 0.04^{\mathrm{d}}$ & $1.50 \pm 0.04^{\mathrm{e}}$ & $2.13 \pm 0.02^{\mathrm{a}}$ & $2.01 \pm 0.01^{\mathrm{b}}$ & $1.90 \pm 0.22^{\mathrm{c}}$ & $2.04 \pm 0.03^{\mathrm{b}}$ \\
\hline 11 & $1.72 \pm 0.01^{\mathrm{c}}$ & $1.31 \pm 0.02^{\mathrm{e}}$ & $1.88 \pm 0.05^{\mathrm{b}}$ & $1.61 \pm 0.04^{\mathrm{d}}$ & $1.85 \pm 0.03^{\mathrm{b}}$ & $1.98 \pm 0.08^{\mathrm{a}}$ \\
\hline 12 & $1.38 \pm 0.01^{\mathrm{c}}$ & $1.43 \pm 0.04^{\mathrm{c}}$ & $1.64 \pm 0.09^{\mathrm{b}}$ & $1.61 \pm 0.12^{\mathrm{b}}$ & $1.63 \pm 0.02^{\mathrm{b}}$ & $1.73 \pm 0.04^{\mathrm{a}}$ \\
\hline 13 & $1.62 \pm 0.06^{\mathrm{d}}$ & $1.43 \pm 0.02^{\mathrm{e}}$ & $1.71 \pm 0.08^{\mathrm{c}}$ & $1.89 \pm 0.07^{\mathrm{b}}$ & $1.73 \pm 0.02^{\mathrm{c}}$ & $2.02 \pm 0.09^{\mathrm{a}}$ \\
\hline 14 & $1.42 \pm<0.01^{\mathrm{b}}$ & $1.34 \pm<0.01^{\mathrm{b}}$ & $1.56 \pm 0.02^{\mathrm{a}}$ & $1.57 \pm 0.05^{\mathrm{a}}$ & $1.49 \pm 0.02^{\mathrm{a}}$ & $1.56 \pm 0.05^{\mathrm{a}}$ \\
\hline 15 & $1.44 \pm 0.05^{\mathrm{c}}$ & $1.32 \pm 0.04^{\mathrm{d}}$ & $1.65 \pm 0.04^{\mathrm{a}}$ & $1.56 \pm 0.03^{\mathrm{b}}$ & $1.56 \pm 0.04^{\mathrm{b}}$ & $1.52 \pm 0.03^{b}$ \\
\hline 16 & $1.45 \pm 0.02^{\mathrm{ns}}$ & $1.39 \pm 0.02^{\mathrm{ns}}$ & $1.45 \pm 0.03^{\mathrm{ns}}$ & $1.46 \pm 0.03^{\mathrm{ns}}$ & $1.41 \pm 0.02^{\mathrm{ns}}$ & $1.39 \pm 0.02^{\mathrm{ns}}$ \\
\hline 17 & $1.33 \pm 0.01^{\mathrm{ns}}$ & $1.32 \pm 0.01^{\mathrm{ns}}$ & $1.36 \pm 0.02^{\mathrm{ns}}$ & $1.37 \pm 0.02^{\mathrm{ns}}$ & $1.38 \pm 0.02^{\mathrm{ns}}$ & $1.33 \pm 0.01^{\mathrm{ns}}$ \\
\hline 18 & $1.35 \pm<0.01^{\mathrm{ms}}$ & $1.36 \pm 0.01^{\mathrm{ns}}$ & $1.34 \pm 0.03^{\mathrm{ns}}$ & $1.32 \pm<0.01^{\mathrm{ns}}$ & $1.36 \pm 0.01^{\mathrm{ns}}$ & $1.31 \pm 0.01^{\mathrm{ns}}$ \\
\hline p-value & 0.018 & 0.075 & 0.092 & 0.025 & 0.018 & 0.126 \\
\hline R - multiple & 0.707 & 0.617 & 0.599 & 0.691 & 0.708 & 0.572 \\
\hline $\mathrm{R}^{2}$ & 0.500 & 0.380 & 0.359 & 0.477 & 0.501 & 0.327 \\
\hline $\mathrm{R}^{2}$ adjusted & 0.393 & 0.247 & 0.222 & 0.365 & 0.394 & 0.183 \\
\hline
\end{tabular}

Means \pm standard deviation of three replicates. Means followed by the different letters on the row indicate significant differences by the Scott-Knott test $(P \leq$ 0.05). BR - Sourdough of brown rice flour without yeast; BRY - Sourdough of brown rice flour with yeast; PB - Sourdough of carioca bean flour without yeast; PBY - Sourdough of carioca bean flour with yeast; VB - Sourdough of cowpea bean flour without yeast; VBY - Sourdough of cowpea bean flour with yeast. Source: Authors (2021).

During spontaneous fermentation, yeasts (Saccharomyces cerevisiae) are subjected to various stresses resulting from the fermentation process itself, such as the presence of other microorganisms (mainly lactic acid bacteria), high concentrations of acids and alcohols and low pH, availability of nutrients, osmotic stress (dough yield, presence of carbohydrates, salts and polysaccharides), oxidative stress (presence of oxygen) and temperature fluctuations (De Vuyst et al., 2016).

The dough's acidity favors a selective environment for the lactic acid bacteria communities since yeasts are particularly more sensitive to the acidic environment (De Vuyst et al., 2016; Kerrebroeck et al., 2017). Thus, lactic acid bacteria are mainly responsible for reducing $\mathrm{pH}$ and increasing the total titratable acidity in the masses, mainly due to the production of lactic and acetic acids during fermentation (Corsetti \& Settanni, 2007; Hammes et al., 2005).

The sourdough acidification favors the exponential growth of heterofermentative lactic acid bacteria, and these stand out from the yeasts, becoming predominant cultures in the dough. Stability in $\mathrm{pH}$ refers to the maturation of the fermented dough. Thus, the propagation of 18 days was enough for the maturation of the sourdoughs, based on the stability of acidity (pH and total titratable acidity) and it is assumed that dominant cultures of lactic acid bacteria may have been established in the masses.

Similar results were found in the literature for a fermented dough to be considered mature $(\mathrm{pH}<3.80)($ Arendt \& Moroni, 2013; De Vuyst et al., 2014). Kerrebroeck et al., (2017) demonstrated that the stability of microbial communities in the mass depends on the propagation time, with at least ten steps necessary to obtain pure and dominant cultures, reducing competitiveness or inhibiting activities metabolic effects of other microorganisms. 
The linear regression was applied and the $\mathrm{p}$-value was significant $(P<0.05)$ for all treatments. The $\mathrm{R}^{2}$ was relatively low but higher in the VB sourdough (0.619) and lower in the BRY sourdough (0.302). Thus, the reduction in $\mathrm{pH}$ was influenced over the time of fermentation and maturation of the sourdough. Still, there is no way to predict how this decrease in $\mathrm{pH}$ occurs through a mathematical model.

Concerning the total titratable acidity, it was observed that there was a great variation during the days of fermentation. Changes in total titratable acidity may be related to the release of other organic acids in the sourdoughs, such as acetic acid and succinic acid. So, it contributed to such fluctuations since total titratable acidity is given in the percentage of lactic acid in this study. Furthermore, the dynamics between the different metabolic activities of microorganisms may have influenced these results. According to Hammes et al. (2005), the acidity of the doughs is directly affected by the substrate metabolism (amylolysis, proteolysis and lipolysis) and the physiological profile of the microorganisms present in the flour during fermentation. A stability in acidity was established on the $16^{\text {th }}$ day, being (in lactic acid): BR $(1.45 \pm 0.02 \%)$, PB $(1.45 \pm 0.03 \%)$, VB $(1.41 \pm 0.02 \%)$, $\operatorname{BRY}(1.39 \pm 0.02 \%)$, PBY $(1.46 \pm 0.03 \%)$ and VBY $(1.39 \pm 0.02 \%)$, remaining stable until the $18^{\text {th }}$ day (in lactic acid): BR $(1.35 \pm 0.01 \%), \operatorname{PB}(1.34 \pm 0.03 \%), \mathrm{VB}(1.36 \pm 0.01 \%)$, BRY $(1.36 \pm 0.01 \%), \operatorname{PBY}(1.32 \pm 0.01 \%)$ and VBY $(1.31 \pm 0.01 \%)$. There was no significant difference $(P>0.05)$ for: VB (p-value 0.092), BRY (p-value 0.074) and VBY (p-value $=0.125)$. The $\mathrm{R}^{2}$ was low in all treatments and from the analysis of variance, it was verified that the model does not predict the results.

\subsubsection{Dough volume increase}

The results obtained for the dough volume increase are shown in Table 8. It was observed that initially, the highest expansion capacity was found in the doughs containing yeast, as it was possible to observe on the $2^{\text {nd }}$ day: a greater expansion area for PBY (74.42 \pm 14.65 AUC), VBY $(56.06 \pm 12.53$ AUC) and BRY (44.64 \pm 8.67 AUC). This initial growth in the doughs is related to the addition of yeasts, which favor, in the first instance, a more significant release of $\mathrm{CO}_{2}$. Later, the inverse was observed, where treatments without yeast showed a greater expansion area. Such characteristics may be related to the gradual and slow release of $\mathrm{CO}_{2}$ by the lactic acid bacteria over time. 
Table 8 - Dough volume increase of sourdough made with brown rice and carioca and cowpea beans flours

\begin{tabular}{|c|c|c|c|c|c|c|}
\hline \multirow{2}{*}{ Time (days) } & \multicolumn{6}{|c|}{ Dough volume increase (Area under the curve - AUC) } \\
\hline & BR & BRY & PB & PBY & VB & VBY \\
\hline 0 & $1.33 \pm 1.89^{c}$ & $28.18 \pm 0.90^{\mathrm{b}}$ & $2.20 \pm 1.23^{\mathrm{c}}$ & $41.57 \pm 5.62^{\mathrm{a}}$ & $4.13 \pm 3.13^{c}$ & $39.67 \pm 2.82^{\mathrm{a}}$ \\
\hline 1 & $18.19 \pm 7.01^{\mathrm{e}}$ & $44.64 \pm 8.67^{c}$ & $24.11 \pm 10.53^{\mathrm{d}}$ & $74.42 \pm 14.65^{\mathrm{a}}$ & $28.06 \pm 8.29^{\mathrm{d}}$ & $56.06 \pm 12.53^{b}$ \\
\hline 2 & $22.34 \pm 8.11^{\mathrm{d}}$ & $49.46 \pm 9.83^{c}$ & $23.88 \pm 9.86^{\mathrm{d}}$ & $71.34 \pm 7.46^{\mathrm{a}}$ & $23.51 \pm 5.95^{\mathrm{d}}$ & $63.26 \pm 7.06^{\mathrm{b}}$ \\
\hline 3 & $46.91 \pm 5.55^{\mathrm{c}}$ & $34.04 \pm 7.88^{\mathrm{d}}$ & $55.85 \pm 9.10^{\mathrm{b}}$ & $47.94 \pm 6.02^{\mathrm{c}}$ & $64.26 \pm 8.56^{\mathrm{a}}$ & $45.81 \pm 8.36^{\mathrm{c}}$ \\
\hline 4 & $37.85 \pm 9.53^{\mathrm{b}}$ & $24.36 \pm 8.97^{c}$ & $57.50 \pm 5.17^{\mathrm{a}}$ & $41.50 \pm 8.37^{\mathrm{b}}$ & $55.62 \pm 4.67^{\mathrm{a}}$ & $41.27 \pm 2.76^{\mathrm{b}}$ \\
\hline 5 & $29.40 \pm 8.00^{c}$ & $25.20 \pm 8.09^{c}$ & $60.22 \pm 8.93^{\mathrm{a}}$ & $46.02 \pm 9.54^{\mathrm{b}}$ & $61.94 \pm 9.04^{\mathrm{a}}$ & $56.46 \pm 9.05^{\mathrm{a}}$ \\
\hline 6 & $26.28 \pm 7.36^{\mathrm{e}}$ & $19.59 \pm 7.95^{\mathrm{f}}$ & $61.36 \pm 9.08^{b}$ & $51.39 \pm 8.23^{\mathrm{d}}$ & $67.76 \pm 10.99^{a}$ & $57.78 \pm 9.99^{c}$ \\
\hline 7 & $25.95 \pm 6.89^{\mathrm{d}}$ & $20.03 \pm 7.29^{\mathrm{d}}$ & $48.52 \pm 8.62^{\mathrm{b}}$ & $36.83 \pm 7.23^{\mathrm{c}}$ & $54.68 \pm 8.43^{\mathrm{a}}$ & $46.70 \pm 5.73^{b}$ \\
\hline 8 & $24.57 \pm 7.50^{\mathrm{d}}$ & $26.37 \pm 12.15^{\mathrm{d}}$ & $43.29 \pm 6.41^{b}$ & $33.63 \pm 9.16^{c}$ & $56.48 \pm 6.32^{\mathrm{a}}$ & $44.48 \pm 5.56^{\mathrm{b}}$ \\
\hline 9 & $27.69 \pm 7.21^{\mathrm{c}}$ & $27.55 \pm 8.36^{\mathrm{c}}$ & $37.07 \pm 9.84^{\mathrm{b}}$ & $27.04 \pm 6.41^{\mathrm{c}}$ & $50.61 \pm 3.77^{\mathrm{a}}$ & $46.04 \pm 6.14^{\mathrm{a}}$ \\
\hline 10 & $25.75 \pm 8.04^{b}$ & $45.97 \pm 12.20^{\mathrm{a}}$ & $30.43 \pm 8.58^{b}$ & $27.72 \pm 7.42^{\mathrm{b}}$ & $50.35 \pm 8.25^{\mathrm{a}}$ & $34.27 \pm 10.18^{b}$ \\
\hline 11 & $19.22 \pm 8.10^{c}$ & $39.85 \pm 9.31^{\mathrm{a}}$ & $21.07 \pm 8.45^{\mathrm{c}}$ & $25.60 \pm 6.84^{b}$ & $28.47 \pm 7.60^{\mathrm{b}}$ & $25.43 \pm 7.14^{\mathrm{b}}$ \\
\hline 12 & $23.42 \pm 6.51^{\mathrm{c}}$ & $28.91 \pm 7.73^{c}$ & $28.62 \pm 6.33^{c}$ & $26.57 \pm 6.88^{c}$ & $53.53 \pm 12.79^{a}$ & $37.47 \pm 7.14^{\mathrm{b}}$ \\
\hline 13 & $35.07 \pm 8.25^{\mathrm{b}}$ & $34.31 \pm 9.50^{\mathrm{b}}$ & $36.19 \pm 6.80^{\mathrm{b}}$ & $37.98 \pm 8.01^{\mathrm{b}}$ & $52.60 \pm 8.74^{\mathrm{a}}$ & $49.96 \pm 8.49^{a}$ \\
\hline 14 & $29.42 \pm 6.00^{c}$ & $32.19 \pm 7.22^{\mathrm{c}}$ & $40.89 \pm 12.27^{\mathrm{b}}$ & $40.22 \pm 6.30^{\mathrm{b}}$ & $61.40 \pm 9.48^{\mathrm{a}}$ & $62.08 \pm 8.57^{\mathrm{a}}$ \\
\hline 15 & $28.99 \pm 6.94^{c}$ & $26.00 \pm 6.31^{\mathrm{c}}$ & $38.50 \pm 6.70^{\mathrm{b}}$ & $42.19 \pm 5.31^{b}$ & $55.32 \pm 7.52^{\mathrm{a}}$ & $55.12 \pm 7.22^{\mathrm{a}}$ \\
\hline 16 & $27.70 \pm 7.10^{c}$ & $24.94 \pm 7.62^{\mathrm{c}}$ & $45.54 \pm 7.48^{\mathrm{b}}$ & $47.96 \pm 7.26^{\mathrm{b}}$ & $58.18 \pm 7.24^{\mathrm{a}}$ & $56.08 \pm 6.77^{\mathrm{a}}$ \\
\hline 17 & $26.64 \pm 7.35^{\mathrm{c}}$ & $28.52 \pm 8.41^{\mathrm{c}}$ & $49.81 \pm 9.38^{\mathrm{b}}$ & $52.87 \pm 9.43^{\mathrm{b}}$ & $59.50 \pm 8.81^{\mathrm{a}}$ & $61.51 \pm 6.65^{\mathrm{a}}$ \\
\hline 18 & $22.06 \pm 6.41^{\mathrm{d}}$ & $25.00 \pm 5.92^{\mathrm{d}}$ & $38.87 \pm 7.12^{\mathrm{c}}$ & $45.42 \pm 6.28^{b}$ & $55.22 \pm 7.45^{\mathrm{a}}$ & $55.30 \pm 8.23^{\mathrm{a}}$ \\
\hline p-value & 0.420 & 0.274 & 0.403 & 0.362 & 0.304 & 0.402 \\
\hline $\mathrm{R}$ - multiple & 0.421 & 0.485 & 0.428 & 0.445 & 0.471 & 0.428 \\
\hline $\mathrm{R}^{2}$ & 0.177 & 0.236 & 0.183 & 0.198 & 0.222 & 0.183 \\
\hline $\mathrm{R}^{2}$ adjusted & 0.001 & 0.072 & 0.008 & 0.026 & 0.055 & 0.008 \\
\hline
\end{tabular}

Means \pm standard deviation of three replicates. Means followed by the different letters on the row indicate significant differences by the Scott-Knott test $(P \leq$ 0.05). BR - Sourdough of brown rice flour without yeast; BRY - Sourdough of brown rice flour with yeast; PB - Sourdough of carioca bean flour without yeast; PBY - Sourdough of carioca bean flour with yeast; VB - Sourdough of cowpea bean flour without yeast; VBY - Sourdough of cowpea bean flour with yeast. Source: Authors (2021).

\subsubsection{Pearson correlation of the $\mathrm{pH}$, total titratable acidity and dough volume increase}

To better understand the results, Pearson's correlation statistic was applied. The Pearson correlation coefficient (r) ranges from -1 to 1 , indicating an inversely or directly proportional correlation between the variables. According to Granato, Calado, \& Jarvis (2014), the correlation coefficient can be evaluated qualitatively and the correlations can be: perfect $(|\mathrm{r}|=1.0)$, strong $(0.80$ $\leq|\mathrm{r}|<1.0)$, moderate $(0.50 \leq|\mathrm{r}| \mathrm{b} 0.80)$, weak $(0.10 \leq|\mathrm{r}| \mathrm{b} 0.50)$, and very weak (almost none) correlation $(0.10 \leq|\mathrm{r}|)$.

Given the above, the variables related to $\mathrm{pH}$ and total titratable acidity of individualized treatments were analyzed and the results are shown in Table 9. It was observed that there was a strong correlation between treatments with and without the addition of yeasts (BR and BRY; PB and PBY; VB and VBY). 
Table 9 - Pearson's correlation for $\mathrm{pH}$, total titratable acidity and dough volume increase of sourdough made with brown rice and carioca and cowpea beans flours

\begin{tabular}{|c|c|c|c|c|c|c|}
\hline Sourdough & pH & & Total & idity (TTA) & Dough & rease (DVI) \\
\hline $\begin{array}{l}\text { Brown rice } \\
\text { flour }\end{array}$ & BR & BRY & BR & BRY & BR & BRY \\
\hline Day & $-0.65^{\#}$ & $-0.69^{\#}$ & $0.71^{\#}$ & $0.59^{\#}$ & 0.15 & -0.18 \\
\hline $\mathrm{pH}-\mathrm{BR}$ & & $0.96^{\#}$ & $-0.90^{\#}$ & $-0.83^{\#}$ & $-0.56^{\#}$ & 0.01 \\
\hline $\mathrm{pH}-\mathrm{BRY}$ & & & $-0.92^{\#}$ & $-0.89^{\#}$ & $-0.53^{\#}$ & 0.16 \\
\hline TTA - BR & & & & $0.91^{\#}$ & $0.38^{\#}$ & -0.05 \\
\hline TTA - BRY & & & & & $0.34^{\#}$ & -0.25 \\
\hline DVI - BR & & & & & & 0.13 \\
\hline $\begin{array}{l}\text { Carioca bean } \\
\text { flour }\end{array}$ & PB & PBY & PB & PBY & PB & PBY \\
\hline Day & $-0.68^{\#}$ & $-0.65^{\#}$ & $0.65^{\#}$ & $0.67^{\#}$ & 0.10 & $-0.34^{\#}$ \\
\hline $\mathrm{pH}-\mathrm{PB}$ & & $0.99^{\#}$ & $-0.83^{\#}$ & $-0.83^{\#}$ & $-0.51^{\#}$ & $0.33^{\#}$ \\
\hline $\mathrm{pH}-\mathrm{PBY}$ & & & $-0.80^{\#}$ & $-0.82^{\#}$ & $-0.55^{\#}$ & $0.37^{\#}$ \\
\hline TTA - PB & & & & $0.96^{\#}$ & 0.09 & $-0.55^{\#}$ \\
\hline TTA - PBY & & & & & 0.14 & $-0.61^{\#}$ \\
\hline DVI - PB & & & & & & 0.21 \\
\hline $\begin{array}{l}\text { Cowpea bean } \\
\text { flour }\end{array}$ & VB & VBY & VB & VBY & VB & VBY \\
\hline Day & $-0.68^{\#}$ & $-0.67^{\#}$ & $0.72^{\#}$ & $0.63^{\#}$ & $0.46^{\#}$ & 0.20 \\
\hline $\mathrm{pH}-\mathrm{VB}$ & & $0.96^{\#}$ & $-0.86^{\#}$ & $-0.83^{\#}$ & $-0.73^{\#}$ & -0.12 \\
\hline $\mathrm{pH}-\mathrm{VBY}$ & & & $-0.83^{\#}$ & $-0.85^{\#}$ & $-0.78^{\#}$ & -0.09 \\
\hline TTA - VB & & & & $0.93^{\#}$ & $0.43^{\#}$ & -0.15 \\
\hline TTA - VBY & & & & & $0.51^{\#}$ & -0.19 \\
\hline DVI - VB & & & & & & $0.47^{\#}$ \\
\hline
\end{tabular}

\#Pearson's correlation with statistical significance $(P \leq 0.05)$. BR - Sourdough of brown rice flour without yeast; BRY - Sourdough of brown rice flour with yeast; PB - Sourdough of carioca bean flour without yeast; PBY - Sourdough of carioca bean flour with yeast; VB - Sourdough of cowpea bean flour without yeast; VBY - Sourdough of cowpea bean flour with yeast. Source: Authors (2021).

The correlation between the day $x \mathrm{pH}$ showed strong negative correlations (variations from -0.65 to -0.69 ) and positive correlations between day $x$ total titratable acidity (variations from 0.59 to 0.73 ) for all treatments. Thus, a greater acidity of the dough was established over time, even as a lowering in $\mathrm{pH}$. Better visualization of this behavior for the treatments can be seen in Figure 2. 
Research, Society and Development, v. 10, n. 16, e303101623992, 2021

(CC BY 4.0) | ISSN 2525-3409 | DOI: http://dx.doi.org/10.33448/rsd-v10n16.23992

Figure 2 - Pearson's correlations regarding the evolution of $\mathrm{pH}$ and total titratable acids (TTA) over time for sourdough made with cowpea beans flour (VB).
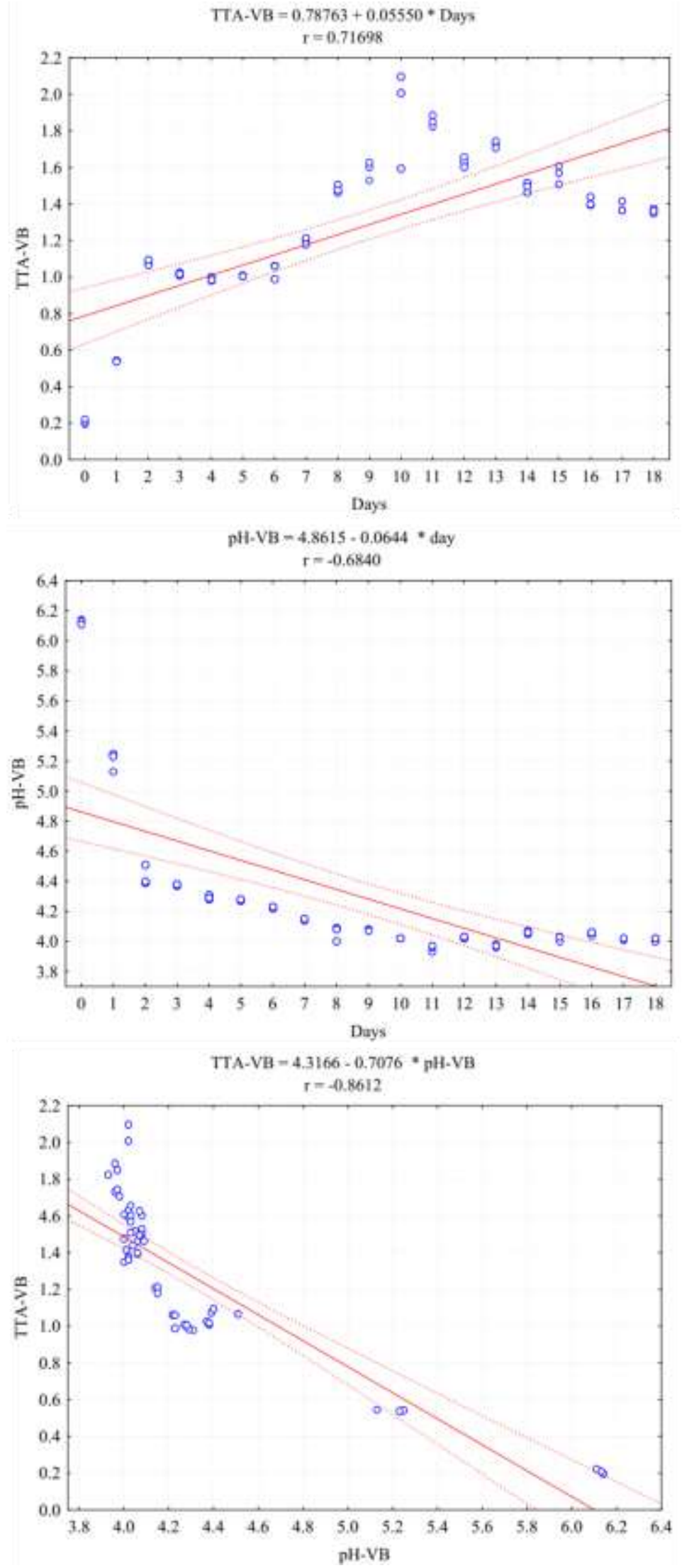

Source: Authors (2021). 
Regarding the dough volume increase, when analyzed individually (Table 9), it is mainly observed that the sourdough BRY did not show correlation with the variables ( $\mathrm{pH}$, total titratable acidity and dough volume increase) and a similar result can be observed for VBY, in which it presented correlation only with the dough volume increase of VB. In contrast, the opposite occurred with $\mathrm{PBY}$, showing correlations only for $\mathrm{pH}$ and total titratable acidity.

A negative correlation between $\mathrm{pH} x$ dough volume increase was observed for treatments that did not add yeasts (BR, PB and VB). However, among the treatments with yeasts, only PBY showed a correlation. Such results indicated that the lower the $\mathrm{pH}$, the higher was the dough volume increase.

Concerning the total titratable acidity, it was observed that the sourdoughs BR and VB showed a positive correlation with dough volume increase. However, this behavior was not observed for the PB treatment, which presented no correlation with total titratable acidity.

On the other hand, the PBY sourdough showed a positive correlation between $\mathrm{pH}$ and dough volume increase. This association can be seen in Table 6 and Table 8 between days $0-6$, and a strong and negative correlation for the total titratable acidity, observed between days 1-6 and 14-18 in Table 7 and Table 8 . The dough volume increase of VBY was only correlated with the dough volume increase of VB.

Strong and positive correlations were found among the different treatments for $\mathrm{pH}$ (ranging from 0.65 to 0.99 ) and total titratable acidity ( 0.65 to 0.59 ), indicating a similar behavior between the sourdoughs. Thus, there was a reduction in $\mathrm{pH}$ and an increase in total titratable acidity in all treatments over time, better represented in Figure 3.

Regarding the dough volume increase in the individual treatments (Table 9), the $\mathrm{pH}$ had a negative correlation with the dough volume increase for all treatments, demonstrating that the lower the $\mathrm{pH}$, the greater the volume of expansion of the sourdoughs. However, a positive correlation was observed between total titratable acidity and dough volume increase for BR and VB sourdoughs.

However, the opposite occurred for the doughs with yeast since BRY and VBY did not present correlations between $\mathrm{pH}$ and total titratable acidity and dough volume increase. Whereas PBY presented a weak correlation, but positive for $\mathrm{pH}$ and negative for total titratable acidity. With higher total titratable acidity, a lower $\mathrm{pH}$ was quantified, and a decrease in dough volume. This association can be seen in Table 6, Table 7 and Table 8.

The correlation of dough volume increase between the different treatments was also observed in Table 10. Given the above, it was observed that there was a strong positive correlation between the dough volume increase and treatments without the addition of yeast ( $\mathrm{BR} x \mathrm{~PB}=0.73$; $\mathrm{BR} x \mathrm{VB}=0.72$; and $\mathrm{PB} x \mathrm{VB}=0.81$ ). This behavior occurs due to the slow and gradual release of $\mathrm{CO}_{2}$ in sourdoughs by spontaneous fermentation oven the days. In the doughs added with starter yeasts occur the opposite, as with the yeast, it provided a boost to initial growth from the rapid release of $\mathrm{CO}_{2}$ in response to the activities carried out by the yeasts added in the first moment.

A weak negative correlation was observed for the dough volume increase between the treatment BRY with PB (-0.29) and VB (-0.28). It demonstrates that the higher the dough volume increase of the sourdough made with carioca beans and cowpea without yeast. On the other hand, the lowest value was found for the BRY of dough volume increase, as better visualized in Figure 4. These results indicate the better expansion capacity of these doughs with bean flour by spontaneous fermentation.

Positive correlations were observed between the sourdoughs elaborated with carioca bean and cowpea being dough volume increase of BR $x$ VB (0.81) and VBY (0.43); PBY $x$ VB (0.62) and VB $x$ VBY (0.47), and they are better represented in Figure 4. Here, the direct correlation between the sourdoughs elaborated with carioca and cowpea is worth noting, whose results showed strong correlations for PB $x$ VB (0.81) and PBY $x$ VB (0.62). On the other hand, a weak correlation was obtained between the dough volume increase of the BRY $x$ PB. 
Figure 3 - Pearson's correlations regarding the evolution of $\mathrm{pH}$ and total titratable acids (TTA) between the sourdough made with brown rice flour with yeast (BRY) and carioca bean beans flour without yeast (PB).
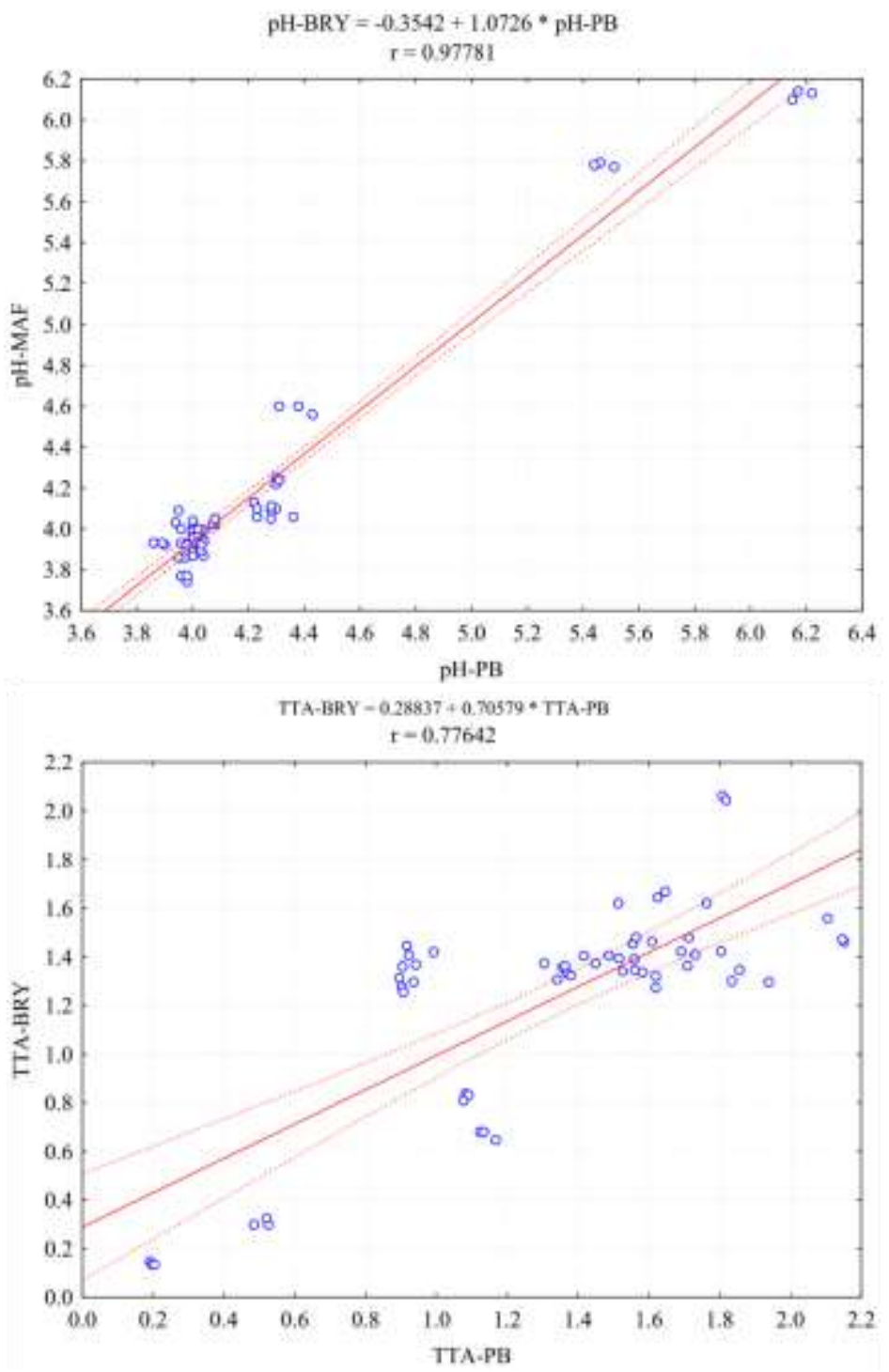

Source: Authors (2021).

Table 10 - Pearson's correlation between the dough volume increase of sourdough made with brown rice and carioca and cowpea beans flours over time.

\begin{tabular}{lllllll}
\hline Samples & BR & BRY & PB & PBY & VB & VBY \\
\hline Days & 0.15 & -0.18 & 0.10 & $-0.34^{*}$ & $0.46^{*}$ & 0.20 \\
BR & & 0.13 & $0.73^{*}$ & $0.29^{*}$ & $0.72^{*}$ & $0.43^{*}$ \\
BRY & & $-0.29^{*}$ & 0.22 & $-0.28^{*}$ & -0.11 \\
PB & & & 0.21 & $0.81^{*}$ & $0.43^{*}$ \\
PBY & & & & -0.03 & $0.62^{*}$ \\
VB & & & & & $0.47^{*}$ \\
\hline
\end{tabular}

*Pearson's correlation with statistical significance $(P \leq 0.05)$. BR - Sourdough of brown rice flour without yeast; BRY - Sourdough of brown rice flour with yeast; PB - Sourdough of carioca bean flour without yeast; PBY - Sourdough of carioca bean flour with yeast; VB - Sourdough of cowpea bean flour without yeast; VBY - Sourdough of cowpea bean flour with yeast. Source: Authors (2021). 
Figure 4 - Pearson's correlations regarding the dough volume increase for the lowest (brown rice flour with yeast $x$ carioca bean flour without yeast) and highest (cowpea bean flour without yeast $x$ carioca bean flour without yeast) dependence.


Source: Authors (2021).

\subsection{Gluten-free dough and bread characterization}

\subsubsection{Proofing time}

The results for the proofing time of the doughs for the preparation of bread corroborate the data for the dough volume increase, where the sourdoughs without the addition of yeast as starter cultures showed the best performance, as seen in Figure 5. 
Figure 5 - Proofing time of doughs for gluten-free breadmaking using sourdoughs obtained from brown rice and carioca and cowpea beans flours and standard sample.

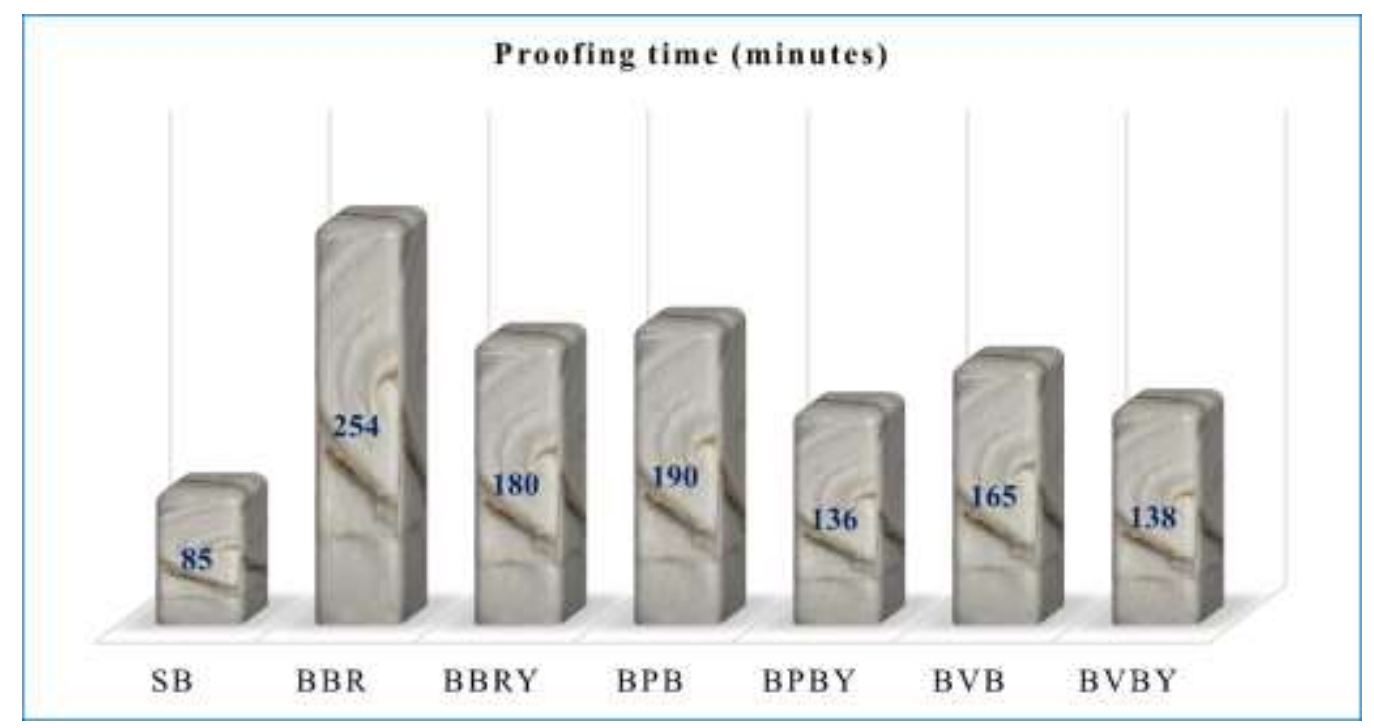

SB - Standard bread; BBR - Bread with sourdough of brown rice flour without yeast; BBRY - Bread with sourdough of brown rice flour with yeast; BPB Bread with sourdough of carioca bean flour without yeast; BPBY - Bread with sourdough of carioca bean flour with yeast; BVB - Bread with sourdough of cowpea bean flour without yeast; BVBY - Bread with sourdough of cowpea bean flour with yeast.

Source: Authors (2021).

\subsection{2 $\mathrm{pH}$ and total titratable acidity}

The $\mathrm{pH}$ and total titratable acidity results of the initial and final doughs and bread are shown in Table 11. It was found that the initial dough, the final dough and the bread made with whole rice flour (BBR and BBRY) had lower $\mathrm{pH}$, while the total titratable acidity increased for all treatments after the initial fermentation. This behavior can be explained by the high content of fermentable carbohydrates present in brown rice flours, as the formation of acids during fermentation depends on the metabolism of carbohydrates (Gänzle et al., 2007).

The addition of substrate in the preparation of the bread doughs, the increase in temperature and fermentation time may have contributed to the variations in $\mathrm{pH}$ and total titratable acidity of the bread doughs. In doughs fermented with bean flour, $\mathrm{pH}$ and total titratable acidity were directly proportional, confirming a probable buffering effect resulting from the proteins in these doughs.

It was observed that the doughs after fermentation showed an increase in total titratable acidity resulting in a decrease in $\mathrm{pH}$, and more significant evidence was found in the doughs with sourdough in the formulation. Furthermore, there were correlations between the $\mathrm{pH}$ and total titratable acidity of the post-fermentation doughs with the loaves, as shown in Table 12 . Similar behavior was found by Jagelaviciute and Cizeikiene (2021) in non-traditional gluten-free sourdough and bread prepared with different grain flours (quinoa, hemp, chia, maize and rice).

During spontaneous fermentation, yeasts (Saccharomyces cerevisiae) are subjected to various stresses resulting from the fermentation process, such as other microorganisms (mainly lactic acid bacteria) and high concentrations of acids and alcohols and low pH. Some studies assume that microorganisms can develop an adaptive process capable of reducing their metabolic and physiological activity in the environment to ensure their survival (Bai et al.,2008). This process is called a viable but non-culturable state. Some microorganisms have their growth capacity inhibited. However, they maintain their viability based on low metabolic activities such as respiratory activity and maintenance of membrane potential (Gustaw, et al., 2021). 
Table 11 - pH and (TTA) total titratable acidity (\% in lactic acid) of the dough before and after fermentation and of gluten-free bread, produced with sourdough from brown rice, carioca and cowpea bean flours.

\begin{tabular}{lllllll}
\hline Sample & Before proofing & \multicolumn{3}{c}{ After proofing } & Bread & \\
\cline { 2 - 7 } & pH & TTA & pH & TTA & pH & TTA \\
\hline SB & $5.39 \pm 0.01^{\mathrm{a}}$ & $0.30 \pm 0.02^{\mathrm{a}}$ & $5.21 \pm<0.01^{\mathrm{a}}$ & $0.25 \pm 0.01^{\mathrm{d}}$ & $5.64 \pm 0.02^{\mathrm{a}}$ & $0.21 \pm<0.01^{\mathrm{d}}$ \\
BBR & $5.44 \pm 0.08^{\mathrm{a}}$ & $0.21 \pm 0.02^{\mathrm{c}}$ & $4.64 \pm 0.01^{\mathrm{e}}$ & $0.43 \pm 0.01^{\mathrm{b}}$ & $4.67 \pm<0.01^{\mathrm{e}}$ & $0.44 \pm 0.01^{\mathrm{b}}$ \\
BBRY & $5.18 \pm<0.01^{\mathrm{b}}$ & $0.28 \pm 0.02^{\mathrm{a}}$ & $4.82 \pm 0.02^{\mathrm{d}}$ & $0.44 \pm 0.01^{\mathrm{b}}$ & $5.03 \pm 0.02^{\mathrm{d}}$ & $0.40 \pm 0.01^{\mathrm{c}}$ \\
BPB & $5.45 \pm<0.01^{\mathrm{a}}$ & $0.25 \pm 0.01^{\mathrm{b}}$ & $5.05 \pm 0.01^{\mathrm{c}}$ & $0.43 \pm 0.01^{\mathrm{b}}$ & $5.04 \pm 0.01^{\mathrm{d}}$ & $0.43 \pm 0.01^{\mathrm{b}}$ \\
BPBY & $5.45 \pm 0.03^{\mathrm{a}}$ & $0.25 \pm 0.01^{\mathrm{b}}$ & $5.15 \pm 0.01^{\mathrm{b}}$ & $0.40 \pm 0.01^{\mathrm{c}}$ & $5.15 \pm<0.01^{\mathrm{b}}$ & $0.41 \pm 0.01^{\mathrm{c}}$ \\
BVB & $5.48 \pm 0.01^{\mathrm{a}}$ & $0.33 \pm 0.02^{\mathrm{a}}$ & $5.05 \pm 0.01^{\mathrm{c}}$ & $0.47 \pm 0.01^{\mathrm{a}}$ & $5.09 \pm<0.01^{\mathrm{c}}$ & $0.44 \pm<0.01^{\mathrm{b}}$ \\
BVBY & $5.50 \pm<0.01^{\mathrm{a}}$ & $0.33 \pm 0.02^{\mathrm{a}}$ & $5.06 \pm 0.01^{\mathrm{c}}$ & $0.43 \pm 0.01^{\mathrm{b}}$ & $5.08 \pm 0.05^{\mathrm{c}}$ & $0.47 \pm 0.01^{\mathrm{a}}$ \\
\hline
\end{tabular}

Means \pm standard deviation of three replicates. Means followed by the different letters on the row indicate significant differences by the Scott-Knott test $(P \leq$ 0.05). SB - Standard bread; BBR - Bread with sourdough of brown rice flour without yeast; BBRY - Bread with sourdough of brown rice flour with yeast; BPB - Bread with sourdough of carioca bean flour without yeast; BPBY - Bread with sourdough of carioca bean flour with yeast; BVB - Bread with sourdough of cowpea bean flour without yeast; BVBY - Bread with sourdough of cowpea bean flour with yeast.

Source: Authors (2021).

This process reverses when the environment returns to favorable conditions, such as the increase in the availability of nutrients. Microorganisms that used to be stagnant tend to resume their metabolic activities. Xu et al. (2021) describe a viable but non-cultivable status of yeasts (Saccharomyces cerevisiae) and the resumption of their metabolic activities when added to a glucose substrate. It is suggestive that during the initial processing, since the ingredients are added and the $\mathrm{pH}$ is increased. These yeasts resume their activities, which may have influenced the results obtained in this study.

Table 12 - Pearson's correlation between $\mathrm{pH}$ and (TTA) total titratable acidity of the dough before and after fermentation and of gluten-free bread, produced with sourdough from brown rice, carioca and cowpea bean flours.

\begin{tabular}{|c|c|c|c|c|c|c|}
\hline Treatments & $\begin{array}{l}\text { pH - before } \\
\text { proofing }\end{array}$ & $\begin{array}{l}\text { TTA - before } \\
\text { proofing }\end{array}$ & $\begin{array}{l}\text { pH - after } \\
\text { proofing }\end{array}$ & $\begin{array}{l}\text { TTA - after } \\
\text { proofing }\end{array}$ & $\begin{array}{l}\text { pH of } \\
\text { bread }\end{array}$ & $\begin{array}{l}\text { TTA of } \\
\text { bread }\end{array}$ \\
\hline Sample & $0.46^{\#}$ & $0.45^{\#}$ & 0.26 & $0.61^{\#}$ & -0.19 & $0.68^{\#}$ \\
\hline $\begin{array}{l}\mathrm{pH}-\text { before } \\
\text { proofing }\end{array}$ & & 0.03 & 0.31 & 0.09 & -0.05 & 0.24 \\
\hline $\begin{array}{l}\text { TTA - before } \\
\text { proofing }\end{array}$ & & & $0.47^{\#}$ & -0.10 & $0.47^{\#}$ & -0.12 \\
\hline $\mathrm{pH}$ - after proofing & & & & $-0.51^{\#}$ & $0.84^{\#}$ & $-0.46^{\#}$ \\
\hline $\begin{array}{l}\text { TTA - after } \\
\text { proofing }\end{array}$ & & & & & $-0.82^{\#}$ & $0.93^{\#}$ \\
\hline $\mathrm{pH}$ of bread & & & & & & $-0.83^{\#}$ \\
\hline
\end{tabular}

\#Pearson's correlation with statistical significance $(P \leq 0.05)$.

Source: Authors (2021).

\subsubsection{Instrumental color, water activity and moisture content}

The instrumental color results of the bread are shown in Table 13. The $L^{*}$ parameter (luminosity) was similar between samples. However, for the parameter $a^{*}$, it was observed that it was higher for bread made with carioca bean flour BPB (5.32 \pm 0.09$)$ and BPBY (5.19 \pm 0.14$)$, representing a more reddish hue. In contrast, bread made with cowpea flour and brown rice flour showed a greater tendency to a yellowness tonality, whose parameter $b^{*}$ was higher than BBR (23.65 \pm 0.50$)$, BBRY

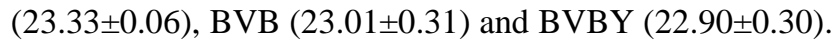


Table 13 - Instrumental color of gluten-free bread produced with sourdough from brown rice, carioca and cowpea bean flours.

\begin{tabular}{lllllll}
\hline Sample & $\boldsymbol{L}^{*}$ & $\boldsymbol{a}^{*}$ & $\boldsymbol{b}^{*}$ & $\Delta \boldsymbol{E}$ & $\boldsymbol{C}^{*}$ & $\boldsymbol{h}^{*}$ \\
\hline SB & $67.87 \pm 0.53^{\text {ns }}$ & $4.14 \pm 0.22^{\mathrm{d}}$ & $22.58 \pm 0.22^{\mathrm{b}}$ & $0.74 \pm 0.03^{\mathrm{d}}$ & $22.96 \pm 0.26^{\mathrm{b}}$ & $79.61 \pm 0.44^{\mathrm{a}}$ \\
BBR & $66.53 \pm 0.63^{\text {ns }}$ & $4.83 \pm 0.04^{\mathrm{b}}$ & $23.65 \pm 0.50^{\mathrm{a}}$ & $2.35 \pm 0.09^{\mathrm{b}}$ & $24.14 \pm 0.49^{\mathrm{a}}$ & $78.44 \pm 0.28^{\mathrm{b}}$ \\
BBRY & $67.24 \pm 0.59^{\mathrm{ns}}$ & $4.63 \pm 0.09^{\mathrm{c}}$ & $23.33 \pm 0.06^{\mathrm{a}}$ & $0.85 \pm 0.03^{\mathrm{d}}$ & $23.78 \pm 0.08^{\mathrm{a}}$ & $78.78 \pm 0.18^{\mathrm{b}}$ \\
BPB & $64.84 \pm 0.51^{\mathrm{ns}}$ & $5.32 \pm 0.09^{\mathrm{a}}$ & $22.61 \pm 0.09^{\mathrm{b}}$ & $3.49 \pm 0.37^{\mathrm{a}}$ & $23.23 \pm 0.10^{\mathrm{b}}$ & $76.76 \pm 0.20^{\mathrm{c}}$ \\
BPBY & $66.19 \pm 0.51^{\mathrm{ns}}$ & $5.19 \pm 0.14^{\mathrm{a}}$ & $22.08 \pm 0.42^{\mathrm{b}}$ & $2.39 \pm 0.09^{\mathrm{b}}$ & $22.69 \pm 0.43^{\mathrm{b}}$ & $76.77 \pm 0.20^{\mathrm{c}}$ \\
BVB & $65.87 \pm 0.40^{\text {ns }}$ & $4.67 \pm 0.07^{\mathrm{c}}$ & $23.00 \pm 0.31^{\mathrm{a}}$ & $2.34 \pm 0.03^{\mathrm{b}}$ & $23.47 \pm 0.32^{\mathrm{b}}$ & $78.51 \pm 0.02^{\mathrm{b}}$ \\
BVBY & $66.65 \pm 0.16^{\text {ns }}$ & $4.54 \pm 0.06^{\mathrm{c}}$ & $22.90 \pm 0.30^{\mathrm{a}}$ & $1.45 \pm 0.13^{\mathrm{c}}$ & $23.35 \pm 0.30^{\mathrm{b}}$ & $78.78 \pm 0.01^{\mathrm{b}}$ \\
\hline
\end{tabular}

Means \pm standard deviation of three replicates. Means followed by the different letters on the row indicate significant differences by the Scott-Knott test $(P \leq$ 0.05). SB - Standard bread; BBR - Bread with sourdough of brown rice flour without yeast; BBRY - Bread with sourdough of brown rice flour with yeast; BPB - Bread with sourdough of carioca bean flour without yeast; BPBY - Bread with sourdough of carioca bean flour with yeast; BVB - Bread with sourdough of cowpea bean flour without yeast; BVBY - Bread with sourdough of cowpea bean flour with yeast.

Source: Authors (2021).

From the determination of $\Delta \mathrm{E}^{*}$, it was possible to infer that bread made with carioca bean flour showed a higher color difference, indicating darker and more noticeable tones than bread made from whole rice flour and cowpea flour. According to Mokrzycki and Tatol (2011), $\Delta \mathrm{E}^{*}$ values between 2.0 and 3.5 demonstrate a perception of color change in the eyes of untrained judges.

There was a more negligible color difference for bread made with sourdough added with yeast $(\mathrm{BBRY}=0.85 \pm 0.03$, $\mathrm{BPBY}=2.39 \pm 0.09$ and $\mathrm{BVBY}=1.45 \pm 0.13$ ). The color parameters showed strong correlations between the acidity of the doughs and bread, results shown in Table 14. Yeast becomes inactivated in an acidic medium, but with the addition of substrates during the manufacture of bread, the acidity tends to decrease and the $\mathrm{pH}$ rises. These behaviors favor the yeasts to exert their activities in the dough again actively. The instrumental color has very different data found in the literature as it can be influenced by the bread formulation and fermentation time and baking temperature.

There was no statistical difference in water activity. Still, higher moisture content was observed in bread made with sourdough added with yeast: being BBRY (42.34 $\pm 0.16 \%)$, BVBY (41.35 $\pm 0.05 \%)$ and BPBY $(40.62 \pm 0.48 \%)$ and less moisture were observed in bread with BVB $(40.03 \pm 0.04 \%)$ and BPB $(40.03 \pm 0.04 \%)$ bean flour (Table 15).

Moisture content is an important quality parameter in bread analysis, as it has a strong influence on final properties, especially on bread texture. The water absorption capacity of the flours is directly related to bread moisture. Dough with high viscosity and little water absorption results in lower specific volume and firm and hard texture. In contrast, gluten-free bread with higher moisture may have a better texture, greater volume and softness (Gallagher et al., 2003). 
Table 14 - Pearson's correlation for physic-chemical parameters of the dough before and after fermentation and of gluten-free bread produced with sourdough from brown rice, carioca and cowpea bean flours.

\begin{tabular}{llllllll}
\hline Parameters & $\boldsymbol{L}^{*}$ & $\boldsymbol{a}^{*}$ & $\boldsymbol{b}^{*}$ & $\boldsymbol{C}^{*}$ & $\boldsymbol{h}^{*}$ & Delta E & $\begin{array}{l}\text { Water } \\
\text { activity }\end{array}$ \\
\hline Sample & -0.42 & 0.27 & -0.20 & -0.17 & -0.31 & 0.31 & -0.40 \\
pH - before proofing & -0.35 & 0.22 & -0.34 & -0.31 & -0.29 & 0.27 & -0.20 \\
TTA - before proofing & 0.20 & $-0.53^{\#}$ & -0.05 & -0.13 & $0.47^{\#}$ & -0.31 & 0.17 \\
pH - after proofing & -0.00 & -0.12 & $-0.75^{\#}$ & $-0.77^{\#}$ & -0.09 & -0.07 & 0.02 \\
TTA - after proofing & -0.52 & $0.50^{\#}$ & 0.28 & 0.35 & -0.39 & $0.50^{\#}$ & $-0.45^{\#}$ \\
pH of bread & 0.40 & $-0.50^{\#}$ & $-0.53^{\#}$ & $-0.61^{\#}$ & 0.32 & $-0.45^{\#}$ & 0.36 \\
TTA of bread & $-0.56^{\#}$ & $0.56^{\#}$ & 0.25 & 0.33 & $-0.45^{\#}$ & $0.53^{\#}$ & $-0.50^{\#}$ \\
$L^{*}$ & & $-0.79^{\#}$ & 0.06 & -0.06 & $0.74^{\#}$ & $-0.96^{\#}$ & $0.50^{\#}$ \\
$a^{*}$ & & & -0.12 & 0.02 & $-0.96^{\#}$ & $0.82^{\#}$ & $-0.60^{\#}$ \\
$b^{*}$ & & & & $0.99^{\#}$ & 0.39 & -0.02 & 0.03 \\
$C^{*}$ & & & & & 0.26 & 0.10 & -0.05 \\
$h^{*}$ & & & & & & $-0.76^{\#}$ & $0.57^{\#}$ \\
$\Delta \mathrm{E}$ & & & & & & $-0.50^{\#}$ \\
\hline
\end{tabular}

\#Pearson's correlation with statistical significance $(P \leq 0.05)$. TTA - total titratable acidity.

Source: Authors (2021).

Table 15 - Water activity and moisture content of gluten-free bread produced with sourdough from brown rice, carioca and cowpea bean flours.

\begin{tabular}{lll}
\hline Sample & Water activity & Moisture content $(\%)$ \\
\hline SB & $0.9968 \pm 0.0024^{\mathrm{ns}}$ & $42.43 \pm 0.02^{\mathrm{a}}$ \\
BBR & $0.9892 \pm 0.0034^{\mathrm{ns}}$ & $40.53 \pm 0.06^{\mathrm{c}}$ \\
BBRY & $0.9926 \pm 0.0034^{\mathrm{ns}}$ & $42.34 \pm 0.16^{\mathrm{a}}$ \\
BPB & $0.9880 \pm 0.0048^{\mathrm{ns}}$ & $40.03 \pm 0.04^{\mathrm{d}}$ \\
BPBY & $0.9832 \pm 0.0032^{\mathrm{ns}}$ & $40.62 \pm 0.48^{\mathrm{c}}$ \\
BVB & $0.9860 \pm 0.0059^{\mathrm{ns}}$ & $39.81 \pm 0.11^{\mathrm{d}}$ \\
BVBY & $0.9917 \pm 0.0008^{\mathrm{ns}}$ & $41.35 \pm 0.05^{\mathrm{b}}$ \\
\hline
\end{tabular}

Means \pm standard deviation of three replicates. Means followed by the different letters on the row indicate significant differences by the Scott-Knott test $(P \leq$ 0.05). SB - Standard bread; BBR - Bread with sourdough of brown rice flour without yeast; BBRY- Bread with sourdough of brown rice flour with yeast; BPB - Bread with sourdough of carioca bean flour without yeast; BPBY- Bread with sourdough of carioca bean flour with yeast; BVB - Bread with sourdough of cowpea bean flour without yeast; BVBY - Bread with sourdough of cowpea bean flour with yeast.

Source: Authors (2021)

\subsubsection{Image analysis, specific volume and instrumental texture of the bread}

The results for image analysis are shown in Table 16. The higher total area was verified in BBRY bread $(36.49 \pm 0.66$ $\mathrm{cm}^{2}$ ), while the total area and number of alveoli of bread made with carioca and cowpea were similar to the area of BBR. However, the alveoli sizes of bread made with carioca beans were significantly smaller BPB $\left(0.12 \pm 0.01 \mathrm{~mm}^{2}\right.$ and BPBY $\left.0.11 \pm 0.01 \mathrm{~mm}^{2}\right)$, while BBRY had a larger alveoli size $\left(0.22 \pm 0.01 \mathrm{~mm}^{2}\right)$. The image of the bread slices can be seen in Figure 6 . There was a strong negative correlation between the total area and the number of alveoli for the instrumental texture parameters. Still, the total area, the number of alveoli and the mean size of the alveoli did not correlate with the specific volume, demonstrating that although BBRY had a larger alveolar structure, its specific volume was lower. 
Table 16 - Image analysis of gluten-free bread produced with sourdough from brown rice, carioca and cowpea bean flours.

\begin{tabular}{lllll}
\hline Sample & Total area $\left(\mathbf{c m}^{2}\right)$ & Number of alveoli & Mean size of the alveoli $\left(\mathbf{m m}^{2}\right)$ & Circularity of alveoli \\
\hline SB & $38.64 \pm 0.93^{\mathrm{a}}$ & $148.37 \pm 10.50^{\mathrm{b}}$ & $0.17 \pm 0.02^{\mathrm{b}}$ & $0.84 \pm 0.01^{\mathrm{ns}}$ \\
BBR & $32.35 \pm 0.42^{\mathrm{b}}$ & $200.60 \pm 2.38^{\mathrm{a}}$ & $0.13 \pm 0.01^{\mathrm{c}}$ & $0.84 \pm 0.01^{\mathrm{ns}}$ \\
BBRY & $36.49 \pm 0.66^{\mathrm{a}}$ & $132.57 \pm 4.25^{\mathrm{b}}$ & $0.22 \pm 0.01^{\mathrm{a}}$ & $0.84 \pm 0.01^{\mathrm{ns}}$ \\
BPB & $32.19 \pm 0.98^{\mathrm{b}}$ & $233.17 \pm 12.36^{\mathrm{a}}$ & $0.12 \pm 0.01^{\mathrm{d}}$ & $0.84 \pm<0.01^{\mathrm{ns}}$ \\
BPBY & $31.94 \pm 2.69^{\mathrm{b}}$ & $224.97 \pm 21.36^{\mathrm{a}}$ & $0.11 \pm 0.01^{\mathrm{d}}$ & $0.83 \pm 0.01^{\mathrm{ns}}$ \\
BVB & $32.97 \pm 1.02^{\mathrm{b}}$ & $165.53 \pm 19.64^{\mathrm{b}}$ & $0.15 \pm 0.01^{\mathrm{c}}$ & $0.85 \pm 0.01^{\mathrm{ns}}$ \\
BVBY & $33.36 \pm 1.43^{\mathrm{b}}$ & $169.20 \pm 3.72^{\mathrm{b}}$ & $0.14 \pm<0.01^{\mathrm{c}}$ & $0.84 \pm 0.01^{\mathrm{ns}}$ \\
\hline
\end{tabular}

Means \pm standard deviation of three replicates. Means followed by the different letter on the row indicate significant differences by the Scott-Knott test $(P \leq$ 0.05). SB - Standard bread; BBR - Bread with sourdough of brown rice flour without yeast; BBRY-Bread with sourdough of brown rice flour with yeast; BPB - Bread with sourdough of carioca bean flour without yeast; BPBY- Bread with sourdough of carioca bean flour with yeast; BVB - Bread with sourdough of cowpea bean flour without yeast; BVBY - Bread with sourdough of cowpea bean flour with yeast.

Source: Authors (2021)

The BPB and BPBY bread had a higher number of alveoli and smaller sizes compared to cowpea bread. Such results may be inferred to be mainly related to the type of protein present in its composition since carioca beans have a higher glutelin content. Glutelins are soluble proteins in dilute acids and bases (Osborne, 1924).

In sourdough, glutenin proteins have more excellent solubility because of the acid levels. Therefore, treatments with carioca beans showed better performance in sourdough and better alveolar uniformity (concerning the size and number of alveoli) in bread, probably due to the better solubility of these proteins. In addition, synergistic effects of carioca beans protein, egg, milk and soy used in the formulation may have helped in the structure of the dough. Thus, it demonstrates the role and structural function of different proteins, favoring better retention/distribution of $\mathrm{CO}_{2}$ during fermentation, thus resulting in a better distribution of the alveoli in this bread.

The results of the texture profile and specific volume of the bread are shown in Table 17. A greater specific volume was observed for BBR $\left(2.04 \pm 0.01 \mathrm{~cm}^{3} \cdot \mathrm{g}^{-1}\right)$ and BVB $\left(2.01 \pm 0.01 \mathrm{~cm}^{3} \cdot \mathrm{g}^{-1}\right)$, while a lower specific volume was observed for BBRY $\left(1.83 \pm 0.02 \mathrm{~cm}^{3} \cdot \mathrm{g}^{-1}\right)$ and BPB $\left(1.87 \pm 0.04 \mathrm{~cm}^{3} \cdot \mathrm{g}^{-1}\right)$. Still, bread made with carioca and cowpea beans had a greater volume when compared to BBRY. Such results may be associated with the water-binding capacity of proteins, favoring dough viscosity and better retention of $\mathrm{CO}_{2}$ during the fermentation stage and in the initial phase of supplying (Brites, Schmiele, \& Steel, 2018).

A change in the relationship pattern between specific volume, firmness and hardness was observed for BBR and BPB. Although they had higher specific volume, there was an increase in firmness and hardness, especially for BVB(38.13 $\pm 4.86 \mathrm{~N}$ and 49.02 $\pm 4.74 \mathrm{~N}$, respectively). The opposite was observed for BBRY that, although it had a lower specific volume, there was less firmness and associated hardness $(27.32 \pm 2.73 \mathrm{~N}$ and $28.71 \pm 1.39 \mathrm{~N}$, respectively). 
Figure 6 - Images of bread slices produced with sourdough from brown rice, carioca and cowpea bean flours.

\section{Sample \\ Standard bread}

Bread with sourdough of brown rice flour without yeast

Bread with sourdough of brown rice flour with yeast

Bread with sourdough of carioca bean flour without yeast

Bread with sourdough of carioca bean flour with yeast

Bread with sourdough of cowpea bean flour without yeast

Bread with sourdough of cowpea bean flour with yeast



\section{Alveoli image}

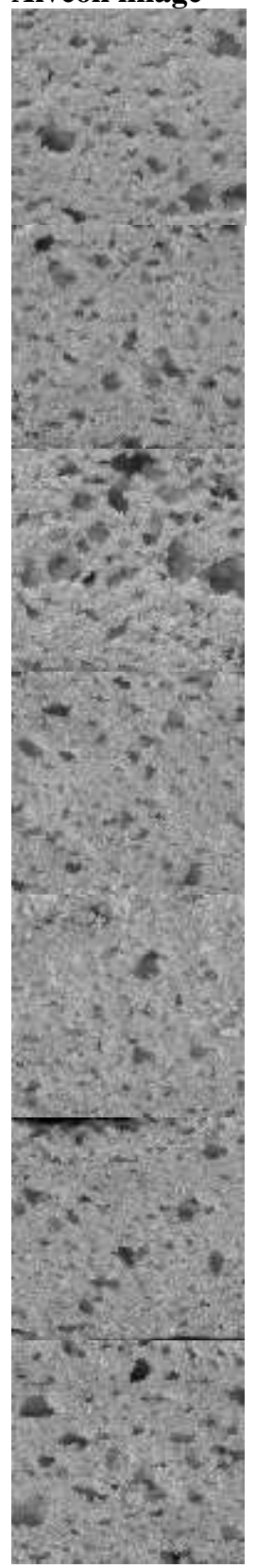

Source: Authors (2021).

Regarding the soluble nitrogen index (Table 18), it was observed that higher protein solubility was found in bread made with cowpea flour BVB $(12.00 \pm 0.23 \%)$ and BVBY $(11.94 \pm 0.31 \%)$ and carioca beans BPB $(10.56 \pm 0.62 \%)$ and BPBY $(10.46 \pm 0.20 \%)$. On the other hand, the bread made with sourdough of whole rice flour - BBR and BBRY, showed a significant difference between them, in which BBR showed better solubility $(\mathrm{BBR}=10.31 \pm 0.33 \%$ and BBRY $=9.52 \pm 0.36 \%)$.

Soluble nitrogen index refers to the solubility of the protein in water. According to Damodaran and Parking, (2017) and Wong, (2018), the interaction between water and protein can be influenced by $\mathrm{pH}$. When $\mathrm{pH}$ values are above or below the isoelectric $\mathrm{pH}$, there is a net charge on the protein's surface that increases electrostatic repulsion. Thus, it induces the interaction between water and protein, resulting in greater hydration of protein residues and increased solubility. Although, as shown in Table 11, BBR had a lower $\mathrm{pH}$ than BBRY and the opposite was observed for the soluble nitrogen index. The Pearson correlation in Table 19 confirms this relationship. 
Table 17 - Specific volume and texture profile analysis of gluten-free bread produced with sourdough from brown rice, carioca and cowpea bean flours.

\begin{tabular}{llllllll}
\hline Parameter & SB & BBR & BBRY & BPB & BPBY & BVB & BVBY \\
\hline Specific volume $\left(\mathrm{cm}^{3} \cdot \mathrm{g}^{-1}\right)$ & $2.08 \pm 0.02^{\mathrm{a}}$ & $2.04 \pm<0.01^{\mathrm{b}}$ & $1.83 \pm 0.02^{\mathrm{e}}$ & $1.87 \pm 0.04^{\mathrm{d}}$ & $1.93 \pm 0.01^{\mathrm{c}}$ & $2.01 \pm 0.01^{\mathrm{b}}$ & $1.94 \pm<0.01^{\mathrm{c}}$ \\
Firmness (N) & $22.28 \pm 1.56^{\mathrm{d}}$ & $32.76 \pm 3.74^{\mathrm{b}}$ & $27.32 \pm 2.73^{\mathrm{c}}$ & $32.08 \pm 2.17^{\mathrm{b}}$ & $32.09 \pm 2.43^{\mathrm{b}}$ & $38.13 \pm 4.86^{\mathrm{a}}$ & $32.33 \pm 1.45^{\mathrm{b}}$ \\
Hardness (N) & $22.85 \pm 1.45^{\mathrm{e}}$ & $39.19 \pm 3.15^{\mathrm{c}}$ & $28.71 \pm 1.40^{\mathrm{d}}$ & $41.79 \pm 3.91^{\mathrm{b}}$ & $37.88 \pm 1.85^{\mathrm{c}}$ & $49.02 \pm 4.74^{\mathrm{a}}$ & $36.41 \pm 1.85^{\mathrm{c}}$ \\
Cohesiviness & $0.55 \pm 0.03^{\mathrm{c}}$ & $0.65 \pm 0.03^{\mathrm{b}}$ & $0.56 \pm 0.04^{\mathrm{c}}$ & $0.64 \pm 0.04^{\mathrm{b}}$ & $0.66 \pm 0.05^{\mathrm{b}}$ & $0.65 \pm 0.02^{\mathrm{b}}$ & $0.70 \pm 0.06^{\mathrm{a}}$ \\
Gumminess (N) & $12.29 \pm 0.63^{\mathrm{d}}$ & $25.39 \pm 3.06^{\mathrm{b}}$ & $15.25 \pm 1.95^{\mathrm{c}}$ & $24.49 \pm 2.19^{\mathrm{b}}$ & $24.72 \pm 1.81^{\mathrm{b}}$ & $29.47 \pm 4.12^{\mathrm{a}}$ & $26.08 \pm 1.30^{\mathrm{b}}$ \\
Chewiness (N) & $10.46 \pm 0.63^{\mathrm{c}}$ & $21.70 \pm 2.93^{\mathrm{b}}$ & $12.78 \pm 1.84^{\mathrm{c}}$ & $20.31 \pm 1.52^{\mathrm{b}}$ & $19.76 \pm 1.64^{\mathrm{b}}$ & $25.27 \pm 4.01^{\mathrm{a}}$ & $21.54 \pm 0.77^{\mathrm{b}}$ \\
Resilience & $0.33 \pm 0.03^{\mathrm{c}}$ & $0.43 \pm 0.02^{\mathrm{b}}$ & $0.34 \pm 0.04^{\mathrm{c}}$ & $0.40 \pm 0.03^{\mathrm{b}}$ & $0.41 \pm 0.04^{\mathrm{b}}$ & $0.42 \pm 0.02^{\mathrm{b}}$ & $0.46 \pm 0.05^{\mathrm{a}}$ \\
\hline
\end{tabular}

Means \pm standard deviation of three replicates. Means followed by the different letters on the row indicate significant differences by the Scott-Knott test $(P \leq$ 0.05). SB - Standard bread; BBR - Bread with sourdough of brown rice flour without yeast; BBRY- Bread with sourdough of brown rice flour with yeast; BPB - Bread with sourdough of carioca bean flour without yeast; BPBY - Bread with sourdough of carioca bean flour with yeast; BVB - Bread with sourdough of cowpea bean flour without yeast; BVBY - Bread with sourdough of cowpea bean flour with yeast.

Source: Authors (2021).

Table 18 - Soluble nitrogen index and in vitro protein digestibility of gluten-free bread produced with sourdough from brown rice, carioca and cowpea bean flours.

\begin{tabular}{lll}
\hline Sample & Soluble nitrogen index $(\%)$ & In vitro protein digestibility $(\%)$ \\
\hline SB & $5.68 \pm 0.02^{\mathrm{d}}$ & $69.34 \pm 3.13^{\mathrm{d}}$ \\
BBR & $10.31 \pm 0.33^{\mathrm{b}}$ & $76.90 \pm 0.89^{\mathrm{c}}$ \\
BBRY & $9.52 \pm 0.36^{\mathrm{c}}$ & $70.60 \pm 3.29^{\mathrm{d}}$ \\
BPB & $10.56 \pm 0.62^{\mathrm{b}}$ & $89.04 \pm 0.90^{\mathrm{a}}$ \\
BPBY & $10.46 \pm 0.22^{\mathrm{b}}$ & $81.55 \pm 1.99^{\mathrm{b}}$ \\
BVB & $12.00 \pm 0.23^{\mathrm{a}}$ & $87.09 \pm 2.39^{\mathrm{a}}$ \\
BVBY & $11.94 \pm 0.31^{\mathrm{a}}$ & $80.89 \pm 1.56^{\mathrm{b}}$ \\
\hline
\end{tabular}

Means \pm standard deviation of three replicates. Means followed by the different letters on the column indicate significant differences by the Scott-Knott test $(P$ $\leq 0.05)$. SB - Standard bread; BBR - Bread with sourdough of brown rice flour without yeast; BBRY- Bread with sourdough of brown rice flour with yeast; BPB - Bread with sourdough of carioca bean flour without yeast; BPBY- Bread with sourdough of carioca bean flour with yeast; BVB - Bread with sourdough of cowpea bean flour without yeast; BVBY - Bread with sourdough of cowpea bean flour with yeast.

Source: Authors (2021)

Regarding the in vitro protein digestibility (Table 18), there was a significant difference between bread made with doughs added with yeast (BBRY, BPBY and BVBY), which presented a lower in vitro protein digestibility when compared to the doughs without yeast (BBR, BPB and BVB). Bread made with carioca bean flour and cowpea had higher in vitro protein digestibility (89.04 \pm 0.90 and $87.09 \pm 2.39 \%$, respectively). The protein digestibility results found in this study were higher than those reported by Rizzello et al. (2014) (68.98-77.85 \%) and Coda et al. (2017b) (63.60-74.10\%). There were no significant correlations between the specific volume of bread and protein digestibility. At the same time, this was strongly correlated with instrumental texture parameters, as described in Table 19.

The intense proteolysis can affect the bread's texture, which is clearly explained in Table 19. Concerning the crumb texture, BPB and BVB bread showed higher protein digestibility when related to greater hardness $(41.79 \pm 3.91 \mathrm{~N}$ and 49.02 $\pm 4.74 \mathrm{~N}$, respectively). Furthermore, it was possible to verify by Pearson's correlation that in vitro protein digestibility is strongly correlated with the evaluated parameters of instrumental texture in Table 19.

Bread made with sourdoughs added with yeast showed lower protein digestibility when compared to those that did not receive the addition of initial yeast (Table 18). However, although they showed lower digestibility, the texture parameters were less affected. This crumb's firmness was mainly lower, possibly due to lower proteolysis $(\mathrm{BBRY}=28.71 \pm 1.40 \mathrm{~N}$, $\mathrm{BPBY}=37.88 \pm 1.85 \mathrm{~N}, \mathrm{BVBY}=36.41 \pm 1.85 \mathrm{~N})$.

Digestibility refers to the importance of the nutritional value of a protein and the different values found may be related 
to other factors such as the processing to which it was submitted and the protein sources. Usually, animal proteins have higher digestibility compared to plants (Cozzolino, 2016). Thus, higher protein digestibility comes from the greater bioavailability of amino acids in sourdoughs due to proteolysis. As a result, proteins are broken into amino acids, peptides and polypeptides, resulting in a nutritional quality increase. Therefore, bread made without adding yeast in the initial dough showed better benefits due to their greater digestibility. The crumb texture can be affected due to an intense proteolytic activity resulting from a significant release of peptides in the medium. Lower macromolecules can reduce the dough's viscosity and influence lower $\mathrm{CO}_{2}$ retention, which may result in this into a thick, gummy bread with a firmer texture.

Legume proteins are susceptible to processing and the environment, and they are easily denatured when exposed to heating and extreme $\mathrm{pH}$. Denaturation allows the exposure of their hydrophobic groups to the surface, thus favoring the formation of gels, emulsions and foams, which are responsible for influencing the characteristics of the dough and the final product (Damodaran \& Parking, 2017). When a high protein content is available in the medium, there may be a reduction in water availability, thus reflecting a greater hardness and firmness of the bread (Ziobro et al., 2013).

Lower cohesiveness was observed in BBRY $(0.56 \pm 0.04)$ and higher in BVBY $(0.70 \pm 0.06)$, and the others (BBR, BPB, BPBY, BVB) did not differ statistically from each other. Cohesiveness is negatively related to bread fragility, so low cohesion indicates a greater susceptibility of the bread to breaking or crumbling, and bread with high cohesion does not quickly disintegrate during chewing.

Gumminess and chewiness are secondary results of texture analysis, which involve firmness, cohesion and elasticity (Teotônio et al., 2021b). The results obtained for these parameters showed a direct and positive relationship with firmness, in which gumminess and chewiness were higher for BVB $(29.47 \pm 4.12 \mathrm{~N}$ and $25.27 \pm 4.01 \mathrm{~N})$ and lower for BBRY $(15.25 \pm 1.95 \mathrm{~N}$ and $12.78 \pm 1.8 \mathrm{~N})$, respectively. Greater resilience was observed in BVBY $(0.46 \pm 0.04)$ and lower in BBRY $(0.34 \pm 0.04)$.

Ziobro et al. (2013) verified the effect of supplementing gluten-free bread with different protein sources (egg albumin, lupine protein, soy protein, collagen and pea protein) and gluten-free bread supplemented with albumin had significantly higher specific volume. According to the authors, changes in specific volume are related to different carbon dioxide retention capacities of the dough by the type of protein used. Furthermore, proteins with the ability to swell and denature at high temperatures, such as albumins, can provide structural support to the starch and hydrocolloids present in the dough, thus influencing the fermentation and early stages of bread baking (Benavent-Gil \& Rosell, 2019; Schmiele et al.,2019; Skendi, Papageorgiou, \& Varzakas, 2021; Wójcik et al., 2021). 
Table 19 - Pearson's correlation for physicochemical, physical and structural characteristics of gluten-free bread produced with sourdough from brown rice, carioca and cowpea bean flours.

\begin{tabular}{|c|c|c|c|c|c|c|c|c|c|c|}
\hline Parameter & TA & NA & AAS & SV & $\mathbf{F}$ & $\mathbf{H}$ & Co & $\mathbf{G}$ & $\mathbf{C h}$ & $\mathbf{R}$ \\
\hline Sample & $-0.50^{\#}$ & 0.16 & -0.33 & -0.30 & $0.61^{\#}$ & $0.62^{\#}$ & $0.66^{\#}$ & $0.70^{\#}$ & $0.69^{\#}$ & $0.68^{\#}$ \\
\hline $\mathrm{pH}-$ before proofing & $-0.53^{\#}$ & $0.49^{\#}$ & $-0.77^{\#}$ & $0.44^{\#}$ & 0.42 & $0.47^{\#}$ & $0.68^{\#}$ & $0.65^{\#}$ & $0.63^{\#}$ & $0.70^{\#}$ \\
\hline TTA - before proofing & 0.30 & $-0.58^{\#}$ & 0.39 & 0.07 & 0.07 & -0.03 & 0.00 & -0.00 & 0.04 & 0.02 \\
\hline TTA - after proofing & $-0.63^{\#}$ & 0.23 & -0.15 & $-0.47^{\#}$ & $0.69^{\#}$ & $0.74^{\#}$ & $0.45^{\#}$ & $0.67^{\#}$ & $0.68^{\#}$ & $0.48^{\#}$ \\
\hline $\mathrm{pH}$ of bread & $0.61^{\#}$ & -0.33 & 0.22 & 0.24 & $-0.55^{\#}$ & $-0.51^{\#}$ & -0.37 & $-0.56^{\#}$ & $-0.55^{\#}$ & -0.41 \\
\hline TTA of bread & $-0.70^{\#}$ & 0.35 & -0.34 & -0.41 & $0.72^{\#}$ & $0.68^{\#}$ & $0.62^{\#}$ & $0.77^{\#}$ & $0.75^{\#}$ & $0.66^{\#}$ \\
\hline$L^{*}$ & $0.64^{\#}$ & $-0.69^{\#}$ & $0.62^{\#}$ & 0.31 & $-0.62^{\#}$ & $-0.65^{\#}$ & $-0.46^{\#}$ & $-0.65^{\#}$ & $-0.65^{\#}$ & $-0.47^{\#}$ \\
\hline$a^{*}$ & $-0.71^{\#}$ & $0.82^{\#}$ & $-0.66^{\#}$ & $-0.48^{\#}$ & 0.40 & $0.46^{\#}$ & 0.36 & $0.46^{\#}$ & 0.41 & 0.35 \\
\hline$h^{*}$ & $0.67^{\#}$ & $-0.83^{\#}$ & $0.70^{\#}$ & $0.47^{\#}$ & -0.32 & -0.41 & -0.38 & -0.42 & -0.36 & -0.35 \\
\hline$\Delta \mathrm{E}$ & $-0.64^{\#}$ & $0.72^{\#}$ & $-0.59^{\#}$ & -0.29 & $0.59^{\#}$ & $0.62^{\#}$ & 0.40 & $0.61^{\#}$ & $0.60^{\#}$ & 0.40 \\
\hline $\mathrm{w}_{\mathrm{a}}$ & $0.47^{\#}$ & $-0.54^{\#}$ & $0.51^{\#}$ & 0.12 & -0.43 & $-0.45^{\#}$ & -0.39 & $-0.49^{\#}$ & -0.43 & -0.38 \\
\hline SNI & $-0.70^{\#}$ & 0.31 & -0.36 & -0.33 & $0.77^{\#}$ & $0.79^{\#}$ & $0.69^{\#}$ & $0.83^{\#}$ & $0.82^{\#}$ & $0.73^{\#}$ \\
\hline IVPD & $-0.64^{\#}$ & $0.52^{\#}$ & $-0.53^{\#}$ & -0.24 & $0.68^{\#}$ & $0.77^{\#}$ & $0.57^{\#}$ & $0.76^{\#}$ & $0.75^{\#}$ & $0.58^{\#}$ \\
\hline Moisture & $0.71^{\#}$ & $-0.69^{\#}$ & $0.70^{\#}$ & -0.04 & $-0.72^{\#}$ & $-0.85^{\#}$ & $-0.57^{\#}$ & $-0.81^{\#}$ & $-0.80^{\#}$ & $-0.59^{\#}$ \\
\hline Ashes & $-0.66^{\#}$ & $0.61^{\#}$ & $-0.63^{\#}$ & -0.31 & $0.53^{\#}$ & $0.62^{\#}$ & $0.54^{\#}$ & $0.63^{\#}$ & $0.60^{\#}$ & $0.52^{\#}$ \\
\hline Proteins & $-0.46^{\#}$ & 0.41 & $-0.61^{\#}$ & -0.00 & $0.44^{\#}$ & $0.51^{\#}$ & $0.73^{\#}$ & $0.62^{\#}$ & $0.56^{\#}$ & $0.71^{\#}$ \\
\hline DC & $0.48^{\#}$ & $-0.53^{\#}$ & $0.64^{\#}$ & 0.15 & -0.42 & $-0.53^{\#}$ & $-0.59^{\#}$ & $-0.58^{\#}$ & $-0.54^{\#}$ & $-0.57^{\#}$ \\
\hline TDF & $-0.57^{\#}$ & $0.63^{\#}$ & $-0.67^{\#}$ & -0.14 & $0.51^{\#}$ & $0.66^{\#}$ & $0.53^{\#}$ & $0.64^{\#}$ & $0.62^{\#}$ & $0.53^{\#}$ \\
\hline EV & 0.42 & $-0.51^{\#}$ & $0.55^{\#}$ & 0.22 & -0.32 & $-0.45^{\#}$ & -0.43 & $-0.45^{\#}$ & -0.43 & -0.41 \\
\hline TA & & $-0.59^{\#}$ & $0.65^{\#}$ & 0.19 & $-0.72^{\#}$ & $-0.65^{\#}$ & $-0.64^{\#}$ & $-0.80^{\#}$ & $-0.77^{\#}$ & $-0.65^{\#}$ \\
\hline NA & & & $-0.90^{\#}$ & -0.09 & 0.18 & 0.38 & $0.47^{\#}$ & 0.41 & 0.33 & $0.45^{\#}$ \\
\hline AAS & & & & -0.15 & -0.35 & $-0.46^{\#}$ & $-0.64^{\#}$ & $-0.59^{\#}$ & $-0.52^{\#}$ & $-0.63^{\#}$ \\
\hline $\mathrm{F}$ & & & & & & $0.84^{\#}$ & $0.56^{\#}$ & $0.93^{\#}$ & $0.95^{\#}$ & $0.60^{\#}$ \\
\hline $\mathrm{H}$ & & & & & & & $0.55^{\#}$ & $0.85^{\#}$ & $0.86^{\#}$ & $0.57^{\#}$ \\
\hline Co & & & & & & & & $0.81^{\#}$ & $0.73^{\#}$ & $0.99^{\#}$ \\
\hline G & & & & & & & & & $0.99^{\#}$ & $0.83^{\#}$ \\
\hline $\mathrm{Ch}$ & & & & & & & & & & $0.77^{\#}$ \\
\hline
\end{tabular}

\#Pearson's correlation with statistical significance $(P \leq 0.05)$. TA $=$ total area; NA = number of alveoli; AAS = alveoli average size; $\mathrm{SV}=$ specific volume; F = firmness; $\mathrm{H}=$ hardness; $\mathrm{Co}=$ cohesiviness; $\mathrm{G}=$ gumminess $\mathrm{Ch}=$ chewiness; $\mathrm{R}=$ resilience; TTA = total titratable acidity; $\mathrm{w}_{\mathrm{a}}=$ water activity; $\mathrm{SNI}=$ soluble nitrogen index; IVPD = in vitro protein digestibility; DC - digestible carbohydrates; TDF = total dietary fiber; EV = energy value.

Source: Authors (2021).

Shevkani et al. (2015) prepared gluten-free muffins with cowpea protein isolates. They observed that incorporating white cowpea protein isolate provided bread with larger volumes, but greater firmness was also associated. A study carried out by Schmiele et al. (2017) found that legume proteins have surfactant properties (emulsifying and aeration), favoring the retention of $\mathrm{CO}_{2}$ in fermentation processes. Hallén et al. (2004) verified that the replacement of wheat flour by native, germinated and/or fermented cowpea flour influenced the technological and structural properties of the doughs and bread, and the results were directly related to the proportion of bean flour added to the dough. The higher replacement by bean flour (20\%) resulted in a lower specific volume of bread. However, the addition of up to $15 \%$ of germinated and/or fermented cowpea flour resulted in a better technological profile.

Boukid et al. (2019) prepared gluten-free bread with the addition of bean flour. They observed that, although it had a negative influence on some characteristics such as browning of the crumb and less chewiness, the bread presented lower starch digestibility and lower glycemic index compared to a bread made only with rice flour.

Coda et al. (2017a) verified that replacing wheat flour with $30 \%$ of fava bean flour (Vicia faba L.) or after natural fermentation negatively influences the texture profile of bread. However, the sourdough of fava flour resulted in bread with a better amino acid profile, higher protein digestibility and lower glycemic index (Coda et al., 2017b).

It is suggested that bread made with carioca bean or cowpea flour may have lower viscosity in the dough. In addition, it is possible to consider an increase in protein hydrolysis during fermentation processes, which may have resulted in an increase 
in polypeptides and/or free amino acids in the dough, thus contributing to the reduction of viscosity and having influenced the final properties of these bread.

Gluten-free bread made with sourdough generally has a lower volume and texture profile than traditional bread. The intense metabolic activity that occurs in the dough during its maturation process seems to influence the final properties of the bread. The main parameters include a higher dough acidity, lower $\mathrm{pH}$, lower $\mathrm{CO}_{2}$ production capacity by lactic acid bacteria, increased starch hydrolysis rate, and increased protein breakdown (Chavan \& Chavan, 2011; De Vuyst \& Neysens, 2005).

In this study, it was possible to verify that $\mathrm{pH}$ and total titratable acid were correlated with the specific volume and texture of the bread. Also, the protein content, nitrogen solubility and protein digestibility were associated with all instrumental texture parameters, as shown in Table 19. These results indicate an important role of natural fermentation and flour composition in influencing the final bread's technological (volume and texture) and nutritional characteristics.

\subsubsection{Proximate composition and total caloric value of bread}

Significant differences were observed in the proximate composition of bread made with sourdough and the results are shown in Table 20. Ash content was significantly lower in bread made with brown rice sour mass (BBR $1.38 \pm 0.03 \%$ and BBRY $1.38 \pm<0.01 \%)$. Bread made with bean flour had higher protein content BPB $(6.71 \pm 0.26 \%)$, BPBY $(7.27 \pm 0.85 \%)$, BVB $(6.89 \pm 0.30 \%)$ and BVBY $(7.22 \pm 0.65 \%)$, while the lowest protein content was observed in wholemeal rice flour bread BBR $(5.58 \pm 0.23 \%)$ and BBRY $(5.00 \pm 0.11 \%)$. This high protein content is directly related to the composition of the flours, as cowpea and carioca bean flours had higher protein contents. Although not significant, a slight reduction in the absolute value of protein in bread made with sourdough was noted (Table 21).

According to Gänzle et al. (2008), protein degradation during dough fermentation is among the main phenomena affecting the general quality of fermented bread. First, proteinases catalyze the degradation of proteins into smaller peptide fractions. Then, peptidases hydrolyze specific peptide bonds, resulting in free amino acids. Intense proteolytic activity was demonstrated during the spread of sourdough with legume flour (Vicia Faba L.), indicating a decrease in peptide content and an increase in the concentration of free amino acids in the doughs (Coda et al., 2017b).

Regarding lipid content, no statistical difference was observed since the fat content was similar between the flours. However, the digestible carbohydrate content and total caloric value were significantly higher in bread made with BPB $(39.05 \pm 2.42 \%$ and $233.98 \pm 1.03 \mathrm{kcal})$ and BBRY $(39.44 \pm 2.60 \%$ and $232.97 \pm 2.83 \mathrm{kcal})$, respectively. The opposite was observed for the dietary fiber content, in which bread made with carioca bean flour and cowpea had higher amounts of BPB (13.12 \pm 0.26 $\%)$, BVB $(11.67 \pm 0.48 \%)$, BPBY $(10.67 \pm 0.15 \%)$ and BVBY $(9.24 \pm 1.07 \%)$. 
Table 20 - Proximate composition (\%) and energy value (kcal. $100 \mathrm{~g}^{-1}$ ) on a wet basis, of gluten-free bread, made with sourdough and brown rice, carioca and cowpea beans flours.

\begin{tabular}{llllllll}
\hline Sample & $\begin{array}{l}\text { Moisture } \\
\text { content }\end{array}$ & Ashes & Proteins & Lipids & $\begin{array}{l}\text { Digestible } \\
\text { carbohydrates } \\
\text { expressed in } \\
\text { glucose) }\end{array}$ & $\begin{array}{l}\text { Total dietary } \\
\text { fibers }\end{array}$ & Energy value \\
& & & & & & & \\
\hline SB & $42.43 \pm 0.02^{\mathrm{a}}$ & $1.35 \pm 0.04^{\mathrm{c}}$ & $5.67 \pm 0.39^{\mathrm{b}}$ & $6.11 \pm 0.04^{\mathrm{ns}}$ & $37.33 \pm 1.29^{\mathrm{b}}$ & $7.05 \pm 0.70^{\mathrm{d}}$ & $227.22 \pm 2.49^{\mathrm{b}}$ \\
BBR & $40.53 \pm 0.06^{\mathrm{c}}$ & $1.38 \pm 0.03^{\mathrm{c}}$ & $5.58 \pm 0.23^{\mathrm{b}}$ & $6.14 \pm 0.06^{\mathrm{ns}}$ & $39.05 \pm 2.42^{\mathrm{a}}$ & $7.27 \pm 0.26^{\mathrm{d}}$ & $233.98 \pm 1.03^{\mathrm{a}}$ \\
BBRY & $42.34 \pm 0.16^{\mathrm{a}}$ & $1.38 \pm<0.01^{\mathrm{c}}$ & $5.00 \pm 0.11^{\mathrm{b}}$ & $6.09 \pm 0.15^{\mathrm{ns}}$ & $39.44 \pm 2.60^{\mathrm{a}}$ & $5.65 \pm 0.59^{\mathrm{e}}$ & $232.97 \pm 2.83^{\mathrm{a}}$ \\
BPB & $40.03 \pm 0.04^{\mathrm{d}}$ & $1.58 \pm 0.02^{\mathrm{a}}$ & $6.71 \pm 0.26^{\mathrm{a}}$ & $6.09 \pm 0.07^{\mathrm{ns}}$ & $32.48 \pm 0.74^{\mathrm{d}}$ & $13.12 \pm 0.26^{\mathrm{a}}$ & $211.51 \pm 0.86^{\mathrm{d}}$ \\
BPBY & $40.62 \pm 0.48^{\mathrm{c}}$ & $1.59 \pm 0.02^{\mathrm{a}}$ & $7.27 \pm 0.85^{\mathrm{a}}$ & $6.07 \pm 0.05^{\mathrm{ns}}$ & $33.81 \pm 0.89^{\mathrm{c}}$ & $10.67 \pm 0.15^{\mathrm{b}}$ & $218.82 \pm 1.36^{\mathrm{c}}$ \\
BVB & $39.81 \pm 0.11^{\mathrm{d}}$ & $1.55 \pm 0.02^{\mathrm{a}}$ & $6.89 \pm 0.30^{\mathrm{a}}$ & $6.16 \pm 0.04^{\mathrm{ns}}$ & $33.87 \pm 1.88^{\mathrm{c}}$ & $11.67 \pm 0.48^{\mathrm{b}}$ & $218.67 \pm 2.13^{\mathrm{c}}$ \\
BVBY & $41.35 \pm 0.05^{\mathrm{b}}$ & $1.49 \pm 0.01^{\mathrm{b}}$ & $7.22 \pm 0.65^{\mathrm{a}}$ & $6.09 \pm 0.17^{\mathrm{ns}}$ & $34.60 \pm 2.36^{\mathrm{c}}$ & $9.24 \pm 1.07^{\mathrm{c}}$ & $222.17 \pm 5.16^{\mathrm{c}}$ \\
\hline
\end{tabular}

Means \pm standard deviation of three replicates. Means followed by the different letters on the column indicate significant differences by the Scott-Knott test $(P$ $\leq 0.05)$. SB - Standard bread; BBR - Bread with sourdough of brown rice flour without yeast; BBRY- Bread with sourdough of brown rice flour with yeast; BPB - Bread with sourdough of carioca bean flour without yeast; BPBY- Bread with sourdough of carioca bean flour with yeast; BVB - Bread with sourdough of cowpea bean flour without yeast; BVBY - Bread with sourdough of cowpea bean flour with yeast.

Source: Authors (2021).

The resolution of the collegiate board - RDC No. 359, of December 23, 2003, defines the size of food servings based on a daily intake of $2000 \mathrm{kcal}$. For bread, the serving size corresponds to $50 \mathrm{~g}$ (Brasil, 2003). The Resolution of the Collegiate Board - RDC No. 54 of November 12, 2012, provides for the technical regulation on complementary nutritional information and determines that it must meet the values established for a food to be considered a source or rich in nutrients in its attachments. For example, foods regarded as protein sources and dietary fiber must contain $6 \mathrm{~g}$ of protein and $2.5 \mathrm{~g}$ of fiber per serving. To be considered rich, they must have at least $12 \mathrm{~g}$ of protein and $5 \mathrm{~g}$ of dietary fiber per serving (Brasil, 2012).

The differences observed between bread made with carioca and cowpea in this study may be associated with their composition, mainly due to their protein fractions. For example, cowpea has a high albumin content, while carioca beans have a higher glutelin content (Montoya, Lallès, Beebe, \& Leterme, 2010). Such characteristics seem to influence the different responses observed.

Bread made with carioca and cowpea beans flours can be considered a protein source, and brown rice bread (standard bread, BBR and BBRY) did not meet this recommendation. Furthermore, the bread elaborated in this study showed to be fiberrich food, except for the BBRY sample, which can be classified as a source of fiber. The relationship between dietary fiber intake and the various health benefits is well elucidated, especially in reducing cholesterol, controlling blood glucose, maintaining body weight and improving bowel function (Chutkan et al. 2012; Kim, 2016). 
Table 21 - Pearson's correlation for physicochemical characteristics and proximate composition of breads.

\begin{tabular}{lllllllll}
\hline Treatments & SNI & IVPD & Moisture & Ashes & Proteins & DC & TDF & EV \\
\hline Sample & $0.83^{\#}$ & $0.66^{\#}$ & $-0.46^{\#}$ & $0.70^{\#}$ & $0.71^{\#}$ & $-0.66^{\#}$ & $0.56^{\#}$ & $-0.53^{\#}$ \\
pH - before proofing & 0.38 & $0.50^{\#}$ & $-0.59^{\#}$ & $0.52^{\#}$ & $0.65^{\#}$ & $-0.62^{\#}$ & $0.59^{\#}$ & $-0.49^{\#}$ \\
TTA - before proofing & 0.09 & -0.04 & 0.25 & 0.05 & 0.28 & -0.17 & -0.03 & -0.08 \\
pH - after proofing & -0.25 & 0.13 & 0.08 & 0.39 & $0.49^{\#}$ & $-0.63^{\#}$ & 0.43 & $-0.61^{\#}$ \\
TTA - after proofing & $0.90^{\#}$ & $0.60^{\#}$ & $-0.58^{\#}$ & $0.45^{\#}$ & 0.24 & -0.21 & 0.33 & -0.15 \\
pH of bread & $-0.68^{\#}$ & -0.33 & $0.50^{\#}$ & -0.13 & 0.02 & -0.15 & -0.04 & -0.19 \\
TTA of bread & $0.95^{\#}$ & $0.63^{\#}$ & $-0.61^{\#}$ & $0.49^{\#}$ & 0.36 & -0.29 & 0.38 & -0.22 \\
$L^{*}$ & $-0.56^{\#}$ & $-0.73^{\#}$ & $0.78^{\#}$ & $-0.69^{\#}$ & -0.39 & $0.62^{\#}$ & $-0.76^{\#}$ & $0.62^{\#}$ \\
$a^{*}$ & $0.49^{\#}$ & $0.61^{\#}$ & $-0.68^{\#}$ & $0.71^{\#}$ & 0.34 & $-0.48^{\#}$ & $0.60^{\#}$ & $-0.47^{\#}$ \\
$b^{*}$ & 0.13 & -0.18 & -0.01 & $-0.47^{\#}$ & -0.43 & $0.60^{\#}$ & $-0.44^{\#}$ & $0.60^{\#}$ \\
$C^{*}$ & 0.19 & -0.09 & -0.11 & -0.37 & -0.39 & $0.54^{\#}$ & -0.36 & $0.53^{\#}$ \\
$h^{*}$ & -0.42 & $-0.61^{*}$ & $0.62^{\#}$ & $-0.79^{\#}$ & $-0.44^{\#}$ & $0.61^{\#}$ & $-0.67^{\#}$ & $0.60^{\#}$ \\
AE & $0.51^{\#}$ & $0.70^{\#}$ & $-0.77^{\#}$ & $0.68^{\#}$ & 0.35 & $-0.54^{\#}$ & $0.70^{\#}$ & $-0.54^{\#}$ \\
Wa & $-0.48^{\#}$ & $-0.53^{\#}$ & $0.64^{\#}$ & $-0.57^{\#}$ & -0.39 & 0.40 & $-0.49^{\#}$ & 0.34 \\
SNI & & $0.72^{\#}$ & $-0.67^{\#}$ & $0.62^{\#}$ & $0.54^{\#}$ & $-0.45^{\#}$ & $0.50^{\#}$ & -0.33 \\
IVPD & & & $-0.86^{\#}$ & $0.81^{\#}$ & $0.55^{\#}$ & $-0.76^{\#}$ & $0.88^{\#}$ & $-0.76^{\#}$ \\
Moisture & & & $-0.71^{\#}$ & $-0.50^{\#}$ & $0.60^{\#}$ & $-0.79^{\#}$ & $0.55^{*}$ \\
Ashes & & & & $0.75^{\#}$ & $-0.86^{\#}$ & $0.84^{\#}$ & $-0.78^{\#}$ \\
Lipids & & & & 0.11 & 0.08 & -0.12 & 0.27 \\
Proteins & & & & & $-0.81^{\#}$ & $0.62^{\#}$ \\
DC & & & & & $-0.58^{\#}$ \\
TDF & & & & & $-0.93^{\#}$ & $0.94^{\#}$ \\
\hline & & & & & $-0.95^{\#}$ \\
\hline
\end{tabular}

\#Pearson's correlation with statistical significance $(P \leq 0.05)$. SNI = soluble nitrogen index; IVPD = in vitro protein digestibility; DC - digestible carbohydrates; $\mathrm{TDF}=$ total dietary fiber; $\mathrm{EV}=$ energy value; $\mathrm{TTA}=$ total titratable acidity; $\mathrm{w}_{\mathrm{a}}=$ water activity.

Source: Authors (2021).

\section{Conclusion}

This work showed that the sourdoughs with whole rice flour, carioca and cowpea, regardless of the addition of biological yeast, showed stability in acidity by reducing $\mathrm{pH}$ and increasing total acidity titratable to a long period of fermentation (18 days). Bread with carioca and cowpea beans flours were affected by their technological properties (loaves specific volume and crumb alveoli and texture). However, this bread showed better nutritional benefit due to the higher minerals, protein and dietary fiber contents, whose appeal as rich in dietary fiber and source of proteins could be assigned. Furthermore, the use of yeast as a starter culture showed a potential behavior to improve the physicochemical and texture properties of the bread. Lower color difference and protein digestibility and higher moisture content were obtained when yeast was used. In addition, they have positively influenced the texture parameters from the reduction in the values of firmness, hardness and chewiness. Therefore, the manufacture of sourdough with carioca bean flour and the addition of yeast showed higher potential for application in the production of gluten-free bread, without losses in technological properties and higher added nutritional value.

\section{Acknowledgments}

The authors would like to thank the Federal University of Jequitinhonha and Mucuri Valleys (UFVJM) and the Institute of Science and Technology (ICT), for the institutional support, and to the Coordination for the Improvement of Higher Education Personnel (CAPES), for financial support (funding code 001).

\section{References}

AACCI. (2010). American Association of Cereal Chemists International. Approved Methods of American Association of Cereal Chemists. AACC, St. Paul.

Aissa, M. F. Ben, Bahloul, S., Monteau, J.-Y., \& Le-Bail, A. (2015). Effect of Temperature on the Solubility of CO 2 in Bread Dough. International Journal of Food Properties, 18(5), 1097-1109. https://doi.org/10.1080/10942910903176360 
AOAC. (2019). Association of Official Analysis Chemists International. Official Methods of Analysis of AOAC International. AOAC, Gaithersburg.

Akeson, W. R., \& Stahmann, M. A. (1964). A Pepsin Pancreatin Digest Index of Protein Quality Evaluation. The Journal of Nutrition, 83(3), 257-261. https://doi.org/10.1093/jn/83.3.257

Aplevicz, K. S. (2013). Identificação de bactérias láticas e leveduras em fermento natural obtido a partir de uva e sua aplicação em pães. Universidade Federal de Santa Catarina

Arendt, E. K., \& Moroni, A. V. (2013). Sourdough and Gluten-Free Products. In Handbook on Sourdough Biotechnology (p. 245-264). Springer US. https://doi.org/10.1007/978-1-4614-5425-0_10

Arendt, E. K., Morrissey, A., Moore, M. M., \& Bello, F. D. (2008). Gluten-free breads. In Gluten-Free Cereal Products and Beverages (p. 289-VII). Elsevier. https://doi.org/10.1016/B978-012373739-7.50015-0

Avilés-Gaxiola, S., Chuck-Hernández, C., \& Serna Saldívar, S. O. (2018). Inactivation Methods of Trypsin Inhibitor in Legumes: A Review. Journal of Food Science, 83(1), 17-29. https://doi.org/10.1111/1750-3841.13985

Bai, F. W., Anderson, W. A., \& Moo-Young, M. (2008). Ethanol fermentation technologies from sugar and starch feedstocks. Biotechnology Advances, 26(1), 89-105. https://doi.org/10.1016/j.biotechadv.2007.09.002

Benavent-Gil, Y., \& Rosell, C. M. (2019). Technological and Nutritional Applications of Starches in Gluten-Free Products. In Starches for Food Application (p. 333-358). Elsevier. https://doi.org/10.1016/B978-0-12-809440-2.00009-5

Bender, D., Fraberger, V., Szepasvári, P., D’Amico, S., Tömösközi, S., Cavazzi, G., \& Schoenlechner, R. (2018). Effects of selected lactobacilli on the functional properties and stability of gluten-free sourdough bread. European Food Research and Technology, 244(6), 1037-1046. https://doi.org/10.1007/s00217-017$3020-1$

Bender, D., \& Schönlechner, R. (2020). Innovative approaches towards improved gluten-free bread properties. Journal of Cereal Science, 91 , 102904. https://doi.org/10.1016/j.jcs.2019.102904

Bolanos, J., Schmiele, M., \& Vernaza, M. G. (2019). Utilización de fréjol, arroz y aguacate en la elaboración de galletas ricas en proteína y libres de gluten. In II INCOFS - Congreso Internacional de Alimentos Ciencia y Tecnología: Quito (Ecuador).

Boukid, F., Folloni, S., Ranieri, R., \& Vittadini, E. (2018). A compendium of wheat germ: Separation, stabilization and food applications. Trends in Food Science \& Technology, 78, 120-133. https://doi.org/10.1016/j.tifs.2018.06.001

Boukid, F., Vittadini, E., Lusuardi, F., Ganino, T., Carini, E., Morreale, F., \& Pellegrini, N. (2019). Does cell wall integrity in legumes flours modulate physiochemical quality and in vitro starch hydrolysis of gluten-free bread? Journal of Functional Foods, 59, 110-118. https://doi.org/10.1016/j.jff.2019.05.034

Boyle, C., Hansen, L., Hinnenkamp, C., \& Ismail, B. P. (2018). Emerging Camelina Protein: Extraction, Modification, and Structural/Functional Characterization. Journal of the American Oil Chemists' Society, 95(8), 1049-1062. https://doi.org/10.1002/aocs.12045

Brasil. (2003). Ministério da Saúde. Agência Nacional de Vigilância Sanitária. Resolução - RDC nº 359, de 23 de dezembro de 2003. Regulamento técnico de porções de alimentos embalados para fins de rotulagem nutricional. Diário Oficial da União, Poder Executivo, Brasília, DF. https://bvsms.saude.gov.br/bvs/saudelegis/anvisa/2003/rdc0359_23_12_2003.html\#: :text=Considerando\%20a\%20necessidade\%20do\%20constante,prote\%C $3 \% \mathrm{~A} 7 \% \mathrm{C} 3 \% \mathrm{~A} 3 \mathrm{o} \% 20 \% \mathrm{C} 3 \% \mathrm{~A} 0 \% 20 \mathrm{sa} \% \mathrm{C} 3 \% \mathrm{BAde} \% 20 \mathrm{da} \% 20$ popula\%C3\%A7\%C3\%A3o\%3B\&text=1\%C2\%BA\%20Aprovar\%20o\%20Regulamento\%20T $\%$ C3\%A 9 cnico,Rotulagem\%20Nutricional $\% 2 \mathrm{C} \% 20$ conforme\%20o\%20Anexo.

Brasil. (2005). Ministério da Saúde. Agência Nacional de Vigilância Sanitária. Resolução - RDC n 263, de 22 de setembro de 2005. Regulamento técnico para produtos de cereais, amidos, farinhas e farelos. Diário Oficial da União, Poder Executivo, Brasília, DF. https://bvsms.saude.gov.br/bvs/saudelegis/anvisa/2005/rdc0263_22_09_2005.html.

Brasil. (2008). Ministério da Agricultura, Pecuária e Abastecimento. Instrução Normativa no ${ }^{\circ}$ 2, de 31 de março de 2008. Regulamento Técnico do Feijão. Diário Oficial da União, Poder Executivo, Brasília, DF. http://sistemasweb.agricultura.gov.br/sislegis/action/detalhaAto.do?method=visualizarAtoPortalM apa\&chave $=294660055$

Brasil. (2012). Ministério da Saúde. Agência Nacional de Vigilância Sanitária. Resolução - RDC nº 54, de 12 de novembro de 2012. Regulamento Técnico sobre Informação Nutricional Complementar. Diário Oficial da União, Poder Executivo, Brasília, DF. https://bvsms.saude.gov.br/bvs/s audelegis/anvisa/2012/rdc0054_12_11_2012.html.

Brites, L. T. G. F., Schmiele, M., \& Steel, C. J. (2018). Gluten-Free Bakery and Pasta Products. In Alternative and Replacement Foods (p. 385-410). Elsevier. https://doi.org/10.1016/B978-0-12-811446-9.00013-7

Carvalho, J. J., Bastos, A. V. S., Saad, J. C. C., Naves, S. S., Soares, F. A. L., \& Vidal, V. M. (2014). Teor e acúmulo de nutrientes em grãos de feijão comum em semeadura direta, sob déficit hídrico. Brazilian Journal of Irrigation and Drainage, 1(1), 104-117. DOI: https://doi.org/10.15809/irriga.2014v1n1p104.

Celmeli, T., Sari, H., Canci, H., Sari, D., Adak, A., Eker, T., \& Toker, C. (2018). The Nutritional Content of Common Bean (Phaseolus vulgaris L.) Landraces in Comparison to Modern Varieties. Agronomy, 8(9), 166. https://doi.org/10.3390/agronomy8090166

Chavan, R. S., \& Chavan, S. R. (2011). Sourdough Technology-A Traditional Way for Wholesome Foods: A Review. Comprehensive Reviews in Food Science and Food Safety, 10(3), 169-182. https://doi.org/10.1111/j.1541-4337.2011.00148.x

Chutkan, R., Fahey, G., Wright, W. L., \& McRorie, J. (2012). Viscous versus nonviscous soluble fiber supplements: Mechanisms and evidence for fiber-specific health benefits. Journal of the American Academy of Nurse Practitioners, 24(8), 476-487. https://doi.org/10.1111/j.1745-7599.2012.00758.x

Coda, R., Kärki, I., Nordlund, E., Heiniö, R.-L., Poutanen, K., \& Katina, K. (2014). Influence of particle size on bioprocess induced changes on technological 
functionality of wheat bran. Food Microbiology, 37, 69-77. https://doi.org/10.1016/j.fm.2013.05.011

Coda, R., Kianjam, M., Pontonio, E., Verni, M., Di Cagno, R., Katina, K., \& Gobbetti, M. (2017). Sourdough-type propagation of faba bean flour: Dynamics of microbial consortia and biochemical implications. International Journal of Food Microbiology, 248, 10-21. https://doi.org/10.1016/j.ijfoodmicro.2017.02.009

Coda, R., Varis, J., Verni, M., Rizzello, C. G., \& Katina, K. (2017). Improvement of the protein quality of wheat bread through faba bean sourdough addition LWT - Food Science and Technology, 82, 296-302. https://doi.org/10.1016/j.1wt.2017.04.062

Corsetti, A., \& Settanni, L. (2007). Lactobacilli in sourdough fermentation. Food Research International, 40(5), 539-558. https://doi.org/10.1016/j.foodres.2006.11.001

Cozzolino, S. M. F. (2016). Biodisponibilidade de nutrientes. Manole.

Crivelenti, F. F., Brites, M. S., Paucar-Menacho, L. M., Schmiele, M., Chang, Y. K., \& Clerici, M. T. P. S. (2013). Desarrollo de galletas tipo cookie con sustitucion parcial de harina de soya germinada. In IV Congreso Internacional Ciencia y Tecnología de los Alimentos: (p. 100-105). Córdoba (Argentina).

Damodaran, S., \& Parking, K. L. (2017). Fennema 's Food Chemistry, Fifth Edition. CRC Press. https://doi.org/10.1201/9781315372914

De Vuyst, L., Van Kerrebroeck, S., Harth, H., Huys, G., Daniel, H.-M., \& Weckx, S. (2014). Microbial ecology of sourdough fermentations: Diverse or uniform? Food Microbiology, 37, 11-29. https://doi.org/10.1016/j.fm.2013.06.002

De Vuyst, Luc, Harth, H., Van Kerrebroeck, S., \& Leroy, F. (2016). Yeast diversity of sourdoughs and associated metabolic properties and functionalities. International Journal of Food Microbiology, 239, 26-34. https://doi.org/10.1016/j.ijfoodmicro.2016.07.018

De Vuyst, Luc, \& Neysens, P. (2005). The sourdough microflora: biodiversity and metabolic interactions. Trends in Food Science \& Technology, 16(1-3), 4356. https://doi.org/10.1016/j.tifs.2004.02.012

Figueroa, A. M. (2016). Caracterização de amidos obtidos de diferentes feijões e sua aplicação em filmes biodegradáveis. Universidade Estadual de Ponta Grossa.

rance. (1993). Décret n 93-1074 du 13 septembre 1993 pris pour l'application de la loi du 1er août 1905 em ce qui concerne certaines catégories de pains. Recuperado de https://www.legifrance.gouv.fr/loda/id/JORFTEXT000000727617/.

Frota, K. de M. G., Morgano, M. A., Silva, M. G. da, Araújo, M. A. da M., \& Moreira-Araújo, R. S. dos R. (2009). Utilização da farinha de feijão-caupi (Vigna unguiculata L. Walp) na elaboração de produtos de panificação. Food Science and Technology, 30(suppl 1), 44-50. https://doi.org/10.1590/S010120612009005000003

Gallagher, E., Gormley, T., \& Arendt, E. (2003). Crust and crumb characteristics of gluten free breads. Journal of Food Engineering, 56(2-3), 153-161. https://doi.org/10.1016/S0260-8774(02)00244-3

Gallagher, E., Gormley, T., \& Arendt, E. (2004). Recent advances in the formulation of gluten-free cereal-based products. Trends in Food Science \& Technology, 15(3-4), 143-152. https://doi.org/10.1016/j.tifs.2003.09.012

Gänzle, M. G., Loponen, J., \& Gobbetti, M. (2008). Proteolysis in sourdough fermentations: mechanisms and potential for improved bread quality. Trends in Food Science \& Technology, 19(10), 513-521. https://doi.org/10.1016/j.tifs.2008.04.002

Gänzle, M. G., Vermeulen, N., \& Vogel, R. F. (2007). Carbohydrate, peptide and lipid metabolism of lactic acid bacteria in sourdough. Food Microbiology, 24(2), 128-138. https://doi.org/10.1016/j.fm.2006.07.006

Gobbetti, M., De Angelis, M., Di Cagno, R., Calasso, M., Archetti, G., \& Rizzello, C. G. (2019). Novel insights on the functional/nutritional features of the sourdough fermentation. International Journal of Food Microbiology, 302, 103-113. https://doi.org/10.1016/j.ijfoodmicro.2018.05.018

Gobbetti, M., Rizzello, C. G., Di Cagno, R., \& De Angelis, M. (2014). How the sourdough may affect the functional features of leavened baked goods. Food Microbiology, 37, 30-40. https://doi.org/10.1016/j.fm.2013.04.012

Granato, D., de Araújo Calado, V. M., \& Jarvis, B. (2014). Observations on the use of statistical methods in Food Science and Technology. Food Research International, 55, 137-149. https://doi.org/10.1016/j.foodres.2013.10.024

Gustaw, K., Niedźwiedź, I., Rachwał, K., \& Polak-Berecka, M. (2021). New Insight into Bacterial Interaction with the Matrix of Plant-Based Fermented Foods. Foods, 10(7), 1603. https://doi.org/10.3390/foods10071603

Hallén, E., İbanoğlu, Ş., \& Ainsworth, P. (2004). Effect of fermented/germinated cowpea flour addition on the rheological and baking properties of wheat flour. Journal of Food Engineering, 63(2), 177-184. https://doi.org/10.1016/S0260-8774(03)00298-X

Hammes, W. P., Brandt, M. J., Francis, K. L., Rosenheim, J., Seitter, M. F. H., \& Vogelmann, S. A. (2005). Microbial ecology of cereal fermentations. Trends in Food Science \& Technology, 16(1-3), 4-11. https://doi.org/10.1016/j.tifs.2004.02.010

Hashimoto, J. M., Schmiele, M., \& Nabeshima, E. H. (2020). Pasting properties of raw and extruded cowpea cotyledons flours. Brazilian Journal of Food Technology, 23. https://doi.org/10.1590/1981-6723.30319

Hashimoto, J. M., Schmiele, M., \& Nabeshima, E. H. (2021). Modelling to obtain expanded cowpea products in a twin screw extruder. Brazilian Journal of Food Technology, 24. https://doi.org/10.1590/1981-6723.11120

Henderson, S. M., \& Perry, R. L. (1976). Size reduction. (Cap. 6, pp. 130-159). Westport: AVI Publishing. (p. 130-159).

Jagelaviciute, J., \& Cizeikiene, D. (2021). The influence of non-traditional sourdough made with quinoa, hemp and chia flour on the characteristics of glutenfree maize/rice bread. LWT, 137, 110457. https://doi.org/10.1016/j.lwt.2020.110457 
Kale, R., \& Deshmukh, R. (2020). Gluten-free products market by type (bakery products, snacks \& rte products, condiments \& dressings, pizzas \& pastas), distribution channel (conventional stores, specialty stores and drugstores \& pharmacies), form \& region - global forecast to 2025 . https://www.alliedmarketresearch.com/gluten-free-products-market

Kalschne, D. L., Silva-Buzanello, R. A. da, Byler, A. P. I., Scremin, F. R., Magalhães Junior, A. M. de, \& Canan, C. (2020). Rice and rice bran from different cultivars: physicochemical, spectroscopic, and thermal analysis characterization. Semina: Ciências Agrárias, 41(6supl2), 3081-3092. https://doi.org/10.5433/1679-0359.2020v41n6Sup12p3081

Kato, L. S. (2014). Caracterização química de feijão para produção de material de referência certificado. Universidade de São Paulo.

Kato, Lilian Seiko, De Nadai Fernandes, E. A., Bacchi, M. A., Sarriés, G. A., \& Reyes, A. E. L. (2015). Elemental characterization of Brazilian beans using neutron activation analysis. Journal of Radioanalytical and Nuclear Chemistry, 306(3), 701-706. https://doi.org/10.1007/s10967-015-4212-4

Kim, H. S. (2016). Blood Glucose Measurement: Is Serum Equal to Plasma? Diabetes \& Metabolism Journal, 40(5), 365. https://doi.org/10.4093/dmj.2016.40.5.365

Khoury, D., Balfour-Ducharme, S., \& Joye, I. J. (2018). A review on the gluten-free diet: Technological and nutritional challenges. Nutrients, 10, 1410. DOI:https://doi.org/10.3390/nu10101410.

Köse, M. A., Ekbiç, E., \& Arıcı, Y. K. (2019). Determination of protein, vitamins, amino acids and mineral element content of Yenice and Pinarli bean. Turk J. Food Agric. Sci., 1(1), 6-11.

Lapčíková, B., Burešová, I., Lapčík, L., Dabash, V., \& Valenta, T. (2019). Impact of particle size on wheat dough and bread characteristics. Food Chemistry, 297, 124938. https://doi.org/10.1016/j.foodchem.2019.06.005

Lima, L. G., Lima, C. T., Barcia, M. T., \& Schmiele, M. (2021). Validação experimental da aplicação de farinhas integrais de sorgo vermelho e feijão-caupi na avaliação de textura da massa e do miolo de bolo tipo muffin. In 14 SLACA - Simpósio Latino Americano de Ciência de Alimentos. Campinas. Brasil.

Lima, L. G., Lima, C. T., Rodrigues, S. M., \& Schmiele, M. (2021). Desenvolvimento de bolo sem glúten com farinhas integrais de arroz, sorgo vermelho e feijão-caupi. In VIII Semana da Integração da UFVJM: Ensino, Pesquisa e Extensão. Diamantina; Brasil.

Mastelini, S. M., Sasso, M. G. A., Campos, G. F. C., Schmiele, M., Clerici, M. T. P. S., Barbin, D. F., \& Barbon, S. (2018). Computer vision system for characterization of pasta (noodle) composition. Journal of Electronic Imaging, 27(05), 1. https://doi.org/10.1117/1.JEI.27.5.053021

Masure, H. G., Fierens, E., \& Delcour, J. A. (2016). Current and forward looking experimental approaches in gluten-free bread making research. Journal of Cereal Science, 67, 92-111. https://doi.org/10.1016/j.jcs.2015.09.009

Merril, A. L., \& Watt, B. K. (1973). Energy value of foods: basis and derivation. U.S. Dept. of Agriculture.

Mokrzycki, W., \& Tatol, M. (2011). Color difference Delta E - A survey. Machine Graphics and Vision, $20(4), 383-411$.

Montoya, C. A., Lallès, J.-P., Beebe, S., \& Leterme, P. (2010). Phaseolin diversity as a possible strategy to improve the nutritional value of common be ans (Phaseolus vulgaris). Food Research International, 43(2), 443-449. https://doi.org/10.1016/j.foodres.2009.09.040

Moroni, A. V., Dal Bello, F., \& Arendt, E. K. (2009). Sourdough in gluten-free bread-making: An ancient technology to solve a novel issue? Food Microbiology, 26(7), 676-684. https://doi.org/10.1016/j.fm.2009.07.001

Neves, N. de A., Gomes, P. T. G., Carmo, E. M. R. do, Silva, B. S., Amaral, T. N., \& Schmiele, M. (2020). Utilização de fermentação natural e jabuticaba (Plinia cauliflora) para melhoria das características de pães de forma. Research, Society and Development, 9(11), e90691110552. https://doi.org/10.33448/rsdv9i11.10552

Neves, N. de A., Gomes, P. T. G., \& Schmiele, M. (2020). Estudo exploratório sobre a elaboração e avaliação de pães de forma com fermentação natural e adição de polpa de araticum (Annona crassiflora Mart.). Research, Society and Development, 9(9), e956998036. https://doi.org/10.33448/rsd-v9i9.8036

Olapade, A. A., \& Oluwole, O. B. (2013). Bread Making Potential of Composite Flour of Wheat-Acha (Digitaria exilis staph) Enriched with Cowpea (Vigna unguiculata L. walp) Flour. Nigerian Food Journal, 31(1), 6-12. https://doi.org/10.1016/S0189-7241(15)30050-3

Olojede, A. O., Sanni, A. I., \& Banwo, K. (2020). Rheological, textural and nutritional properties of gluten-free sourdough made with functionally important lactic acid bacteria and yeast from Nigerian sorghum. LWT, 120, 108875. https://doi.org/10.1016/j.1wt.2019.108875

Osborne, T. B. (1924). The vegetable proteins. Journal of the Society of Chemical Industry, 43(17), 440-440. https://doi.org/10.1002/jctb.5000431704.

Pereira, A. S., Shitsuka, D. M., Pereira, F. J., \& Shitsuka, R. (2018). Metodologia da pesquisa científica. UFSM. Recuperado de https://repositorio.ufsm.br/bitstream/handle/1/15824/Lic_Computacao_Metodologia-Pesquisa-Cientifica.pdf?sequence=1.

Phillips, R. D., McWatters, K. H., Chinnan, M. S., Hung, Y.-C., Beuchat, L. R., Sefa-Dedeh, S., \& Saalia, F. K. (2003). Utilization of cowpeas for human food. Field Crops Research, 82(2-3), 193-213. https://doi.org/10.1016/S0378-4290(03)00038-8

Reis, A. S., \& Schmiele, M. (2021). Custard apple puree, fructooligosaccharide and soy protein hydrolysate as alternative ingredients in low carb pound cake. Journal of Food Science and Technology, 58(9), 3632-3644. https://doi.org/10.1007/s13197-021-05155-9.

Rizzello, C. G., Calasso, M., Campanella, D., Angelis, M., \& Gobbetti, M. (2014). Use of sourdough fermentation and mixture of wheat, chickpea, lentil and bean flours for enhancing the nutritional, texture and sensory characteristics of white bread. International Journal of Food Microbiology, $180,78-87$.

Rocchetti, G., Lucini, L., Rodriguez, J. M. L., Barba, F. J., \& Giuberti, G. (2019). Gluten-free flours from cereals, pseudocereals and legumes: Phenolic fingerprints and in vitro antioxidant properties. Food Chemistry, 271, 157-164. https://doi.org/10.1016/j.foodchem.2018.07.176 
Rodrigues, S. M., Teotônio, D. O., Andressa, I., Nascimento, G. K. S., Pereira, P. A. P., \& Schmiele, M. (2021). Aplicação de crioprotetores em massa congelada de pão sem glúten. In IV Simpósio de Engenharia de Alimentos. Montes Claros.

Santos, J. L., Gomes, L. R., Nascimento, G. K. S., \& Schmiele, M. (2021). Elaboração de barra de cereais com uso de resíduo de mosturação de cerveja desidratado, proteína hidrolisada de soja e gelatina. In VIII Semana da Integração da Ufvjm: Ensino, Pesquisa e Extensão. Diamantina; Brasil.

Santos, V. S., Rodrigues, R. S., Jaekel, L. Z., Chang, Y. K., \& Schmiele, M. (2017). Dough rheology and technological characteristics of pan bread elaborated with the partial replacement of wheat flour via isolated soy protein and transglutaminase. (p. 219-246). Nova Science Publishers.

Schmiele, M., Silveira, M. P., Leite, L. L., Felisberto, M. H. F., Clerici, M. T. P. S., \& Chang, Y. K. (2019). Macarrão instantâneo fonte de proteína e com alto teor de fibra alimentar (p. 893-901). Montes Claros: ICA/UFMG.

Schmiele, Marcio, Ferrari Felisberto, M. H., Pedrosa Silva Clerici, M. T., \& Chang, Y. K. (2017). Mixolab ${ }^{\mathrm{TM}}$ for rheological evaluation of wheat flour partially replaced by soy protein hydrolysate and fructooligosaccharides for bread production. LWT - Food Science and Technology, 76, 259-269. https://doi.org/10.1016/j.lwt.2016.07.014

Schmiele, Marcio, Sampaio, U. M., \& Pedrosa Silva Clerici, M. T. (2019). Basic Principles. In Starches for Food Application (p. 1-22). Elsevier. https://doi.org/10.1016/B978-0-12-809440-2.00001-0

Schmiele, Marcio, Silva, L. H. da, Costa, P. F. P. da, Rodrigues, R. da S., \& Chang, Y. K. (2011). Influência da adição de farinha integral de aveia, flocos de aveia e isolado proteico de soja na qualidade tecnológica de bolo inglês. Boletim do Centro de Pesquisa de Processamento de Alimentos, 29(1). https://doi.org/10.5380/cep.v29i1.22751

Shevkani, K., Kaur, A., Kumar, S., \& Singh, N. (2015). Cowpea protein isolates: Functional properties and application in gluten-free rice muffins. LWT - Food Science and Technology, 63(2), 927-933.

Skendi, A., Papageorgiou, M., \& Varzakas, T. (2021). High Protein Substitutes for Gluten in Gluten-Free Bread. Foods, 10(9), 1997. https://doi.org/10.3390/foods10091997

Souza, A. R., Costa, B. A. F., Amaral, E. F. G., Santos, B, T., Clerici, M. T. P. S., \& Schmiele, M. (2017). Crioprotetores melhoram as propriedades de pasta da farinha de arroz para panificação sem glúten. In III JEA-Jornada Regional Sudeste de Engenharia de Alimentos. Diamantina.

Souza, E. C., Cordeiro, D. A., \& Schmiele, M. (2021). Desempenho do bagaço de oliva, azeite de oliva extravirgem e proteína hidrolisada de soja em muffins. In VIII Semana da Integração UFVJM: Ensino, Pesquisa e Extensão. Diamantina; Brasil.

Tasiguano, B. L., Villarreal, C., Schmiele, M., \& Vernaza, M. G. (2019). Efecto del tiempo de Cocción del Zapallo (Cucurbita maxima) y la adición de Glucosa Oxidasa en el Aumento de Almidón Resistente del Pan de Molde. Información tecnológica, 30(3), 167-178. https://doi.org/10.4067/S0718-07642019000300167

Teotônio, D. de O., Costa, B. A. F. da, Gomes, P. T. G., Santos, M. P., Amaral, E. F. G., Clerici, M. T. P. S., \& Schmiele, M. (2021). Fructo-oligosaccharides, hydrolyzed soy protein and yeast (Saccharomyces sp.) extract as potential cryoprotectans in gluten-free frozen dough and bread quality. Research, Society and Development, 10(3), e44510313556. https://doi.org/10.33448/rsd-v10i3.13556

Teotônio, D. de O., Rodrigues, S. M., Leoro, M. G. V., Pereira, P. A. P., \& Schmiele, M. (2021). Potentialities of using cryoprotectants in gluten-free frozen dough and microwave baking as an emerging technology. Research, Society and Development, 10(6), e12410615674. https://doi.org/10.33448/rsd-v10i6.15674

Vagadia, B. H., Vanga, S. K., \& Raghavan, V. (2017). Inactivation methods of soybean trypsin inhibitor - A review. Trends in Food Science \& Technology, 64, 115-125. https://doi.org/10.1016/j.tifs.2017.02.003

Van Kerrebroeck, S., Maes, D., \& De Vuyst, L. (2017). Sourdoughs as a function of their species diversity and process conditions, a meta-analysis. Trends in Food Science \& Technology, 68, 152-159. https://doi.org/10.1016/j.tifs.2017.08.016

Vasantharaja, R., Abraham, L. S., Inbakandan, D., Thirugnanasambandam, R., Senthilvelan, T., Jabeen, S. K. A., \& Prakash, P. (2019). Influence of seaweed extracts on growth, phytochemical contents and antioxidant capacity of cowpea (Vigna unguiculata L. Walp). Biocatalysis and Agricultural Biotechnology, 17 , 589-594. https://doi.org/10.1016/j.bcab.2019.01.021

Wójcik, M., Różyło, R., Schönlechner, R., \& Berger, M. V. (2021). Physico-chemical properties of an innovative gluten-free, low-carbohydrate and high proteinbread enriched with pea protein powder. Scientific Reports, 11(1), 14498. https://doi.org/10.1038/s41598-021-93834-0

Wong, D. W. S. (2018). Mechanism, and Theory in Food Chemistry. Springer International Publishing.

Worku, A., \& Sahu, O. (2017). Significance of fermentation process on biochemical properties of Phaseolus vulgaris (red beans). Biotechnology Reports, 16, 511. https://doi.org/10.1016/j.btre.2017.09.001

Xu, Z., Lu, Z., Soteyome, T., Ye, Y., Huang, T., Liu, J., \& Peters, B. M. (2021). Polymicrobial interaction between Lactobacillus and Saccharomyces cerevisiae : coexistence-relevant mechanisms. Critical Reviews in Microbiology, 47(3), 386-396. https://doi.org/10.1080/1040841X.2021.1893265

Yang, Q.-Q., Gan, R.-Y., Ge, Y.-Y., Zhang, D., \& Corke, H. (2018). Polyphenols in Common Beans ( Phaseolus vulgaris L.): Chemistry, Analysis, and Factors Affecting Composition. Comprehensive Reviews in Food Science and Food Safety, 17(6), 1518-1539. https://doi.org/10.1111/1541-4337.12391

Zaheer, M., Ahmed, S., \& Hasan, M. (2020). Vigna unguiculata (L.) Walp. (Papilionaceae): A review of medicinal uses, phytochemistry and pharmacology. Journal of Pharmacognosy and Phytochemistry.

Zanotto, D. L., \& Bellaver, C. (1996). Método de determinação da granulometria de ingredientes para uso em rações de suínos e aves. Condórdia: EMBRAPA.

Zapata-Luna, R. L., Ayora-Talavera, T., Pacheco, N., García-Márquez, E., Espinosa-Andrews, H., Ku-González, Á., \& Cuevas-Bernardino, J. C. (2021). Physicochemical, morpho-structural and rheological characterization of starches from three Phaseolus spp. landraces grown in Chiapas. Journal of Food 
Research, Society and Development, v. 10, n. 16, e303101623992, 2021

(CC BY 4.0) | ISSN 2525-3409 | DOI: http://dx.doi.org/10.33448/rsd-v10n16.23992

Measurement and Characterization, 15(2), 1410-1421. https://doi.org/10.1007/s11694-020-00739-z

Ziobro, R., Witczak, T., Juszczak, L., \& Korus, J. (2013). Supplementation of gluten-free bread with non-gluten proteins. Effect on dough rheological properties and bread characteristic. Food Hydrocolloids, 32(2), 213-220. https://doi.org/10.1016/j.foodhyd.2013.01.006 